\title{
Herpetofauna of Veer Narmad South Gujarat University, Surat, India
}

\author{
Dikansh S. Parmar and Shantilal K. Tank \\ Department of Biosciences, Veer Narmad South Gujarat University, Surat, Gujarat, India \\ (ophiophagus_hannah10@yahoo.com)
}

$\mathrm{R}$ eptiles and Amphibians play a crucial role in global ecology; they are recognized as significant elements and key biological indicators in the terrestrial and aquatic ecosystems in which they occur. Of the approximately 10,700 known species of reptiles (Uetz et al. 2018), 518 species (34 turtles, 3 crocodilians, 279 snakes, and 202 lizards) in 28 families occur in India (Aengals et al. 2011). Of the nearly 8,000 currently recognized species of amphibians (AmphibiaWeb 2019), about 238 species in 10 families have been recorded in India (Daniels 2005).

The number of species continues to grow with the application of new species concepts, molecular methods, and more intensive surveys. For example, approximately 290 species of snakes are now recognized as occurring in India. In the state of Gujarat, 61 species of snakes (48 terrestrial, semi-aquatic, and arboreal species and 13 species of seasnakes) have been recorded (Desai 2017). The amphibian fauna of Gujarat is comprised of 20 species (one caecilian and 19 anurans) in five families and 13 genera (Vyas 2008).

We investigated the herpetofauna of Veer Narmad South Gujarat University (http://www.VNSGU.ac.in/dept/uni/profile.php) and herein report observations of 30 species of reptiles and amphibians in 14 families and 24 genera.

\section{Study Area and Objectives}

Veer Narmad South Gujarat University (VNSGU) is a public university located in the city of Surat, Gujarat, India $\left(21^{\circ} 09^{\prime} 12^{\prime \prime} \mathrm{N}, 72^{\circ} 47^{\prime} 00^{\prime \prime} \mathrm{E}\right)$. The university campus is spread over 210 acres and comprises more than 100 buildings, including 25 departments, a library, stadiums, dormitories, and other structures. The grounds also include small grasslands, lawns, lakes, and wooded areas (www.VNSGU.ac.in). Maximum summer temperatures can exceed $44^{\circ} \mathrm{C}$, whereas winters are dry and cold with temperatures as low as $10^{\circ} \mathrm{C}$. Most rain falls from July to September. The average annual rainfall for the city is $1,143 \mathrm{~mm}$ (Surat Municipal Corporation: https://www. suratmunicipal.gov.in/TheCity/Weather).

We surveyed the entire VNSGU campus with the following objectives: (I) To determine the biodiversity of reptiles and amphibians. (II) To determine the present distribution of reptiles and amphibians. (III) To evaluate the present status of each species (common, uncommon and rare) at VNSGU campus. (IV) To obtain a rough estimate of the population size of each species. (V) To collect baseline information on habitat and ecological niches. (VI) To identify the threats, if any, to reptiles and amphibians.

\section{Methods and Materials}

To address the objectives listed above, we employed the following methods: (I) Visual encounter surveys, including those focused on construction sites and greenhouses and localities near water, plus plot and transect surveys. (II) Examination of indirect evidence such as shells, shed skins, foot and scale prints, and sounds. (III) Examination of rescue records. (IV). Driving roads and identifying roadkilled specimens. (V) Collecting secondary information through interviews with faculty, students, security personnel, landscapers, and other university employees, as well as local residents. (VI) Reviews of published literature.

To confirm the identity of some squamates, we counted scales using the methods of Dowling (1951). We determined sex by everting hemipenes of males. We measured snout-vent length (SVL) to the posterior margin of the cloacal plate. For amphibians, we measured SVL to the vent.

At various times of day and night from December 2017 through December 2018, we spent a total of 72 days (6-7 h/ day, generally $4 \mathrm{~h}$ during the day and $2-3 \mathrm{~h}$ at night) in the field. We identified animals using the diagnostic keys and descriptions in Boulenger (1890, 1920), Daniel (1963a, 1963b, 1975, 1983, 2002), Daniels (1997a, 1997b, 1997c, 2005), Desai (2017), Smith $(1935,1943)$, and Whitaker and Captain (2004, 2008); nomenclature is from Daniel $(1983,2002)$, Das (1994, 2003), Dutta (1997), Das and Dutta (1998), Whitaker and Captain (2004, 2008), and Uetz et al. (2018).

\section{Results}

We recorded 30 species of reptiles and amphibians in 24 genera and 14 families (7 anurans, 1 turtle, 22 squamates). 


\section{REPTILES: TURTLES}

Testudines: Trionychidae

Common Flap-shelled Turtle, Lisseymys punctata (Fig. 1): We found a total of ten of these turtles in Nakshetra van, a wooded area in VNSGU. One was dead when found at 1145 $\mathrm{h}$ in leaf litter at the side of a lake within Nakshetra van. The second was found alive at night near the sign at the entrance of Nakshetra van by Mehul K. Modi, campus chief security officer. Eight others were swimming in the lake or basking on mudflats from 1300 to $1700 \mathrm{~h}$ almost every day. When disturbed, the basking turtles quickly enter the water.

Threats to this species include road mortality during migration in the monsoon season, collection for food, and habitat destruction. Also noteworthy is the use of ground shells as a cure for skin diseases by many people in nearby The Dangs District, where populations of these turtles are severely depleted. Dangis believe that the powder is the best remedy for diseases like smallpox and chickenpox (Vyas 2007).

\section{REPTILES: LIZARDS}

\section{Squamata: Gekkonidae}

Brook's House Gecko, Hemidactylus brookii (Fig. 2): One gecko with a shed tail was recorded at VNSGU on 24 June 2018 at 2040 h. It was on the wall of the Girnar Dormitory. Another was in ecdysis, with the shed skin hanging on its tail. Two others were at the Bapalal Department's greenhouse (Department of Botany) on 8 December 2018, one inside at $1210 \mathrm{~h}$ and another outside at $1235 \mathrm{~h}$. We observed three geckos on 11 December, one at $1130 \mathrm{~h}$ near the Sahyadri Dormitory on the dome-like wall of an enclosed drainage system and two outside a netted greenhouse at the Rural Studies Department at $1229 \mathrm{~h}$ and $1243 \mathrm{~h}$ hiding beneath a thin aluminum sheet. Four found on 14 December 2018 at 1336 h
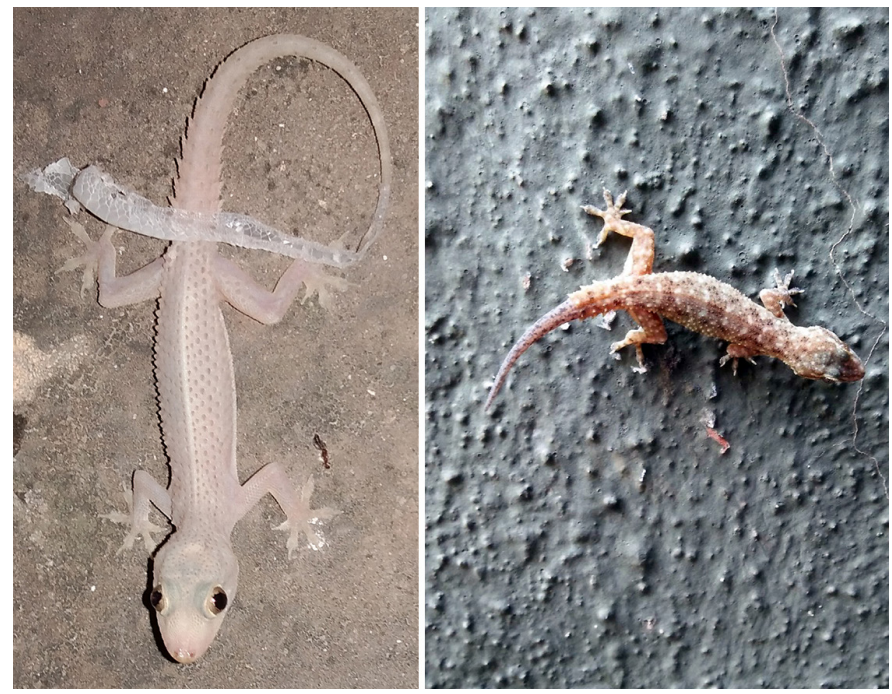

Fig. 2. A Brook's House Gecko (Hemidactylus brookii) with shed skin on the tip of its tail (left) and another individual with a distinct, albeit light dorsal pattern (right). Photographs by D.S. Parmar.

behind the wall of the Rural Studies Department had taken shelter in a waste box filled with another small empty box and covered with two thick gunny sacks.

Color and patterns vary considerably in these geckos, with individuals varying at different times (Daniel 1983; Laxmi Narayana et al. 2016). These medium-sized geckos (to 135 $\mathrm{mm}$ in total length) are primarily nocturnal (its noisy "chuck chuk" call is often heard after dusk) but can occasionally be found during the day. The species is common throughout India, where they live on trees, under rocks and stones, and on buildings. They breed in hot weather; females lay two spherical eggs that hatch in about 39 days (Daniel 1983).

Northern House Gecko, Hemidactylus flaviviridis (Fig. 3): We recorded one individual at $2100 \mathrm{~h}$ on 13 June 2018

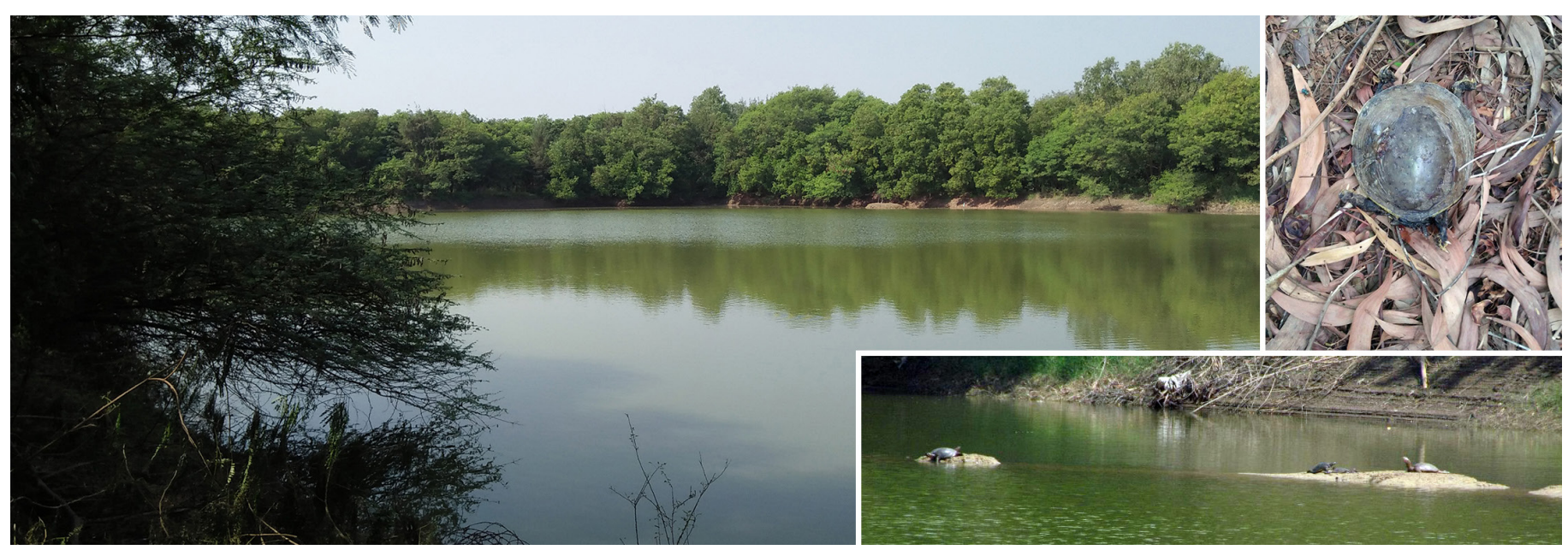

Fig. 1. Nakshetra van is a planted area with many trees and a lake where Common Flap-shelled Turtles (Lisseymys punctata) were found (left). A dead turtle found in Nakshetra van (upper right) and turtles basking on mud flats (lower right). Photographs by Dr. S.K Tank (left), M.H. Patel (upper right), and D.S. Parmar (lower right). 


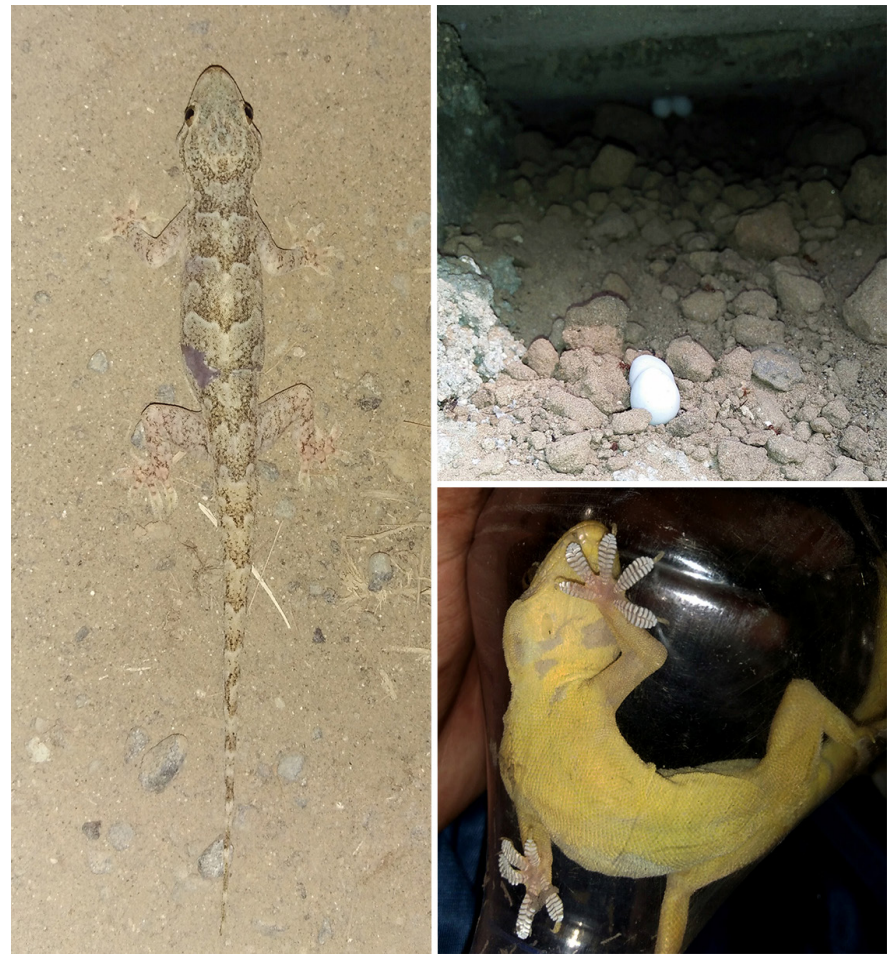

Fig. 3. A Northern House Gecko (Hemidactylus flaviviridis) with a bite mark on its trunk, which might have occurred during mating (left); two pairs of eggs in a cavity in a concrete block at the Rural Studies Department (upper right); and the bright yellow venter of a captured gecko (lower right). Photographs by D.S. Parmar.

on the wall of the Girnar Dormitory and another on a roadside near the Girnar Dormitory on 21 September at 2434 h. The latter had a bite mark on the left side of its trunk, which might have occurred during mating (e.g., Chatterjee et al. 2011). Although not evident in the photograph, we noted chromogenicity or development of a color patch, which occurs in the precoital, coital, and postcoital stages of mating and fades after 2-3 h (Chatterjee et al. 2011). We found three more individuals on a wall of the Rural Studies Department on 9 December 2018 at $1620 \mathrm{~h}$, two more at $1351 \mathrm{~h}$ on 11 December $1351 \mathrm{~h}$ hiding in the cavities of concrete blocks, and four eggs in another block in the same wall.

As in other house geckos, color and patterns vary considerably (Daniel 1983). This gecko is larger than other Indian house geckos, reaching total lengths of about 180 $\mathrm{mm}$ (Daniel 1983). Like its relatives, it is active primarily at night but is seen occasionally during the day. This species is common throughout the Indian Subcontinent, where it frequently functions as a human commensal (Daniel 1983). It usually lays two (rarely one or three) spherical eggs in a clutch; the hatching period ranges from 33 to 54 days (Daniel 1983).

\section{Southern House Gecko, Hemidactylus frenatus (Fig. 4):} We recorded one individual at $1239 \mathrm{~h}$ on 18 April 2018, two juveniles at $1310 \mathrm{~h}$ on 26 April 2018, and three more on 9 December 2018, all in Nakshetra van. One of the latter (an

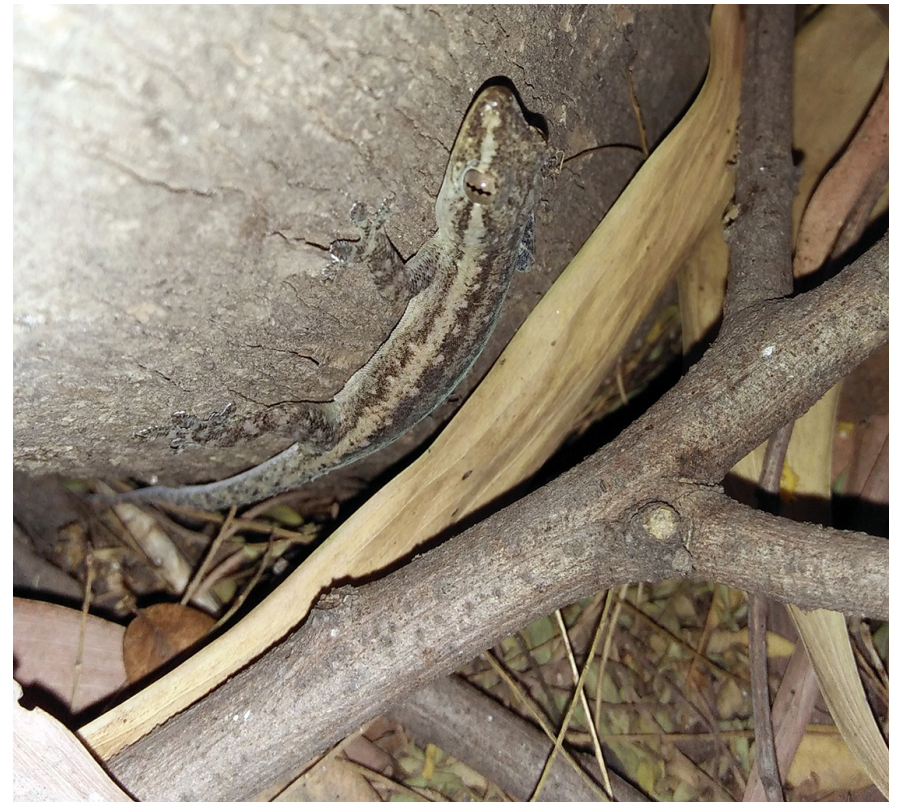

Fig. 4. An adult Southern House Gecko (Hemidactylus frenatus) from the Nakshetra van. Photograph by D.S. Parmar.

adult) was hiding in a three-foot long cylindrical box near a water pump at $1554 \mathrm{~h}$; when disturbed, it came out of the box and hid at the bottom of a tree trunk. The others were juveniles on two different trees.

This species is a small (to $\sim 125 \mathrm{~mm}$ in total length), mostly nocturnal gecko occasionally encountered during the day (Daniel 1983). One captive individual changed from distinctly patterned to patternless and colorless. Most frequently seen in houses, these geckos also forage on trees. We also found them on rocks and under stones. This is perhaps the noisiest of the Indian geckos (Daniel 1983). It breeds in hot weather, laying two spherical eggs, which hatch in about 42 days (Daniel 1983).

\section{Squamata: Agamidae}

Indian Garden Lizard, Calotes versicolor (Fig. 5): We recorded one individual at $2045 \mathrm{~h}$ on 24 November 2018 in the cafeteria of a men's dormitory and another in the garden of the Aquatic Department at 1403 h on 1 December 2018.

This is the most abundant agamid lizard in Indian and the only species of Calotes found at VNSGU.

It is a medium-sized (to $-490 \mathrm{~mm}$ total length) diurnally active arboreal lizard found in gardens, scrubland, hedges, and forest (Daniel 1983). Clutches consist of 11-23 eggs, which hatch in about 34-47 days (Daniel 2002).

\section{Squamata: Lygosomidae ${ }^{1}$}

Gunther's Supple Skink, Lygosoma guentheri (Fig. 6): We found one skink in a rarely accessed forested area at $1350 \mathrm{~h}$ on 12 December 2018 near the Rural Studies Department. DP found another individual in Surat in 2012.

${ }^{1}$ These families sometimes are considered subfamilies of Scincidae. 

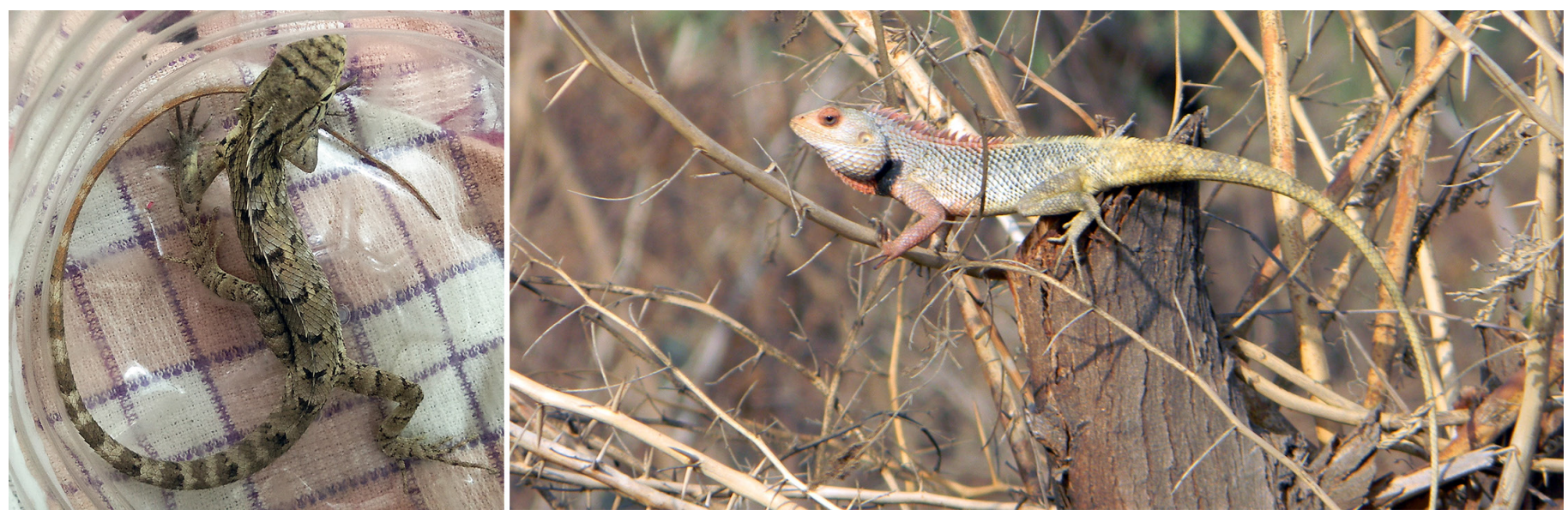

Fig. 5. An adult Indian Garden Lizard (Calotes versicolor) rescued from the cafeteria (left) and an adult male in breeding colors (right). Photographs by D.S. Parmar (left) and M.H. Patel (right).
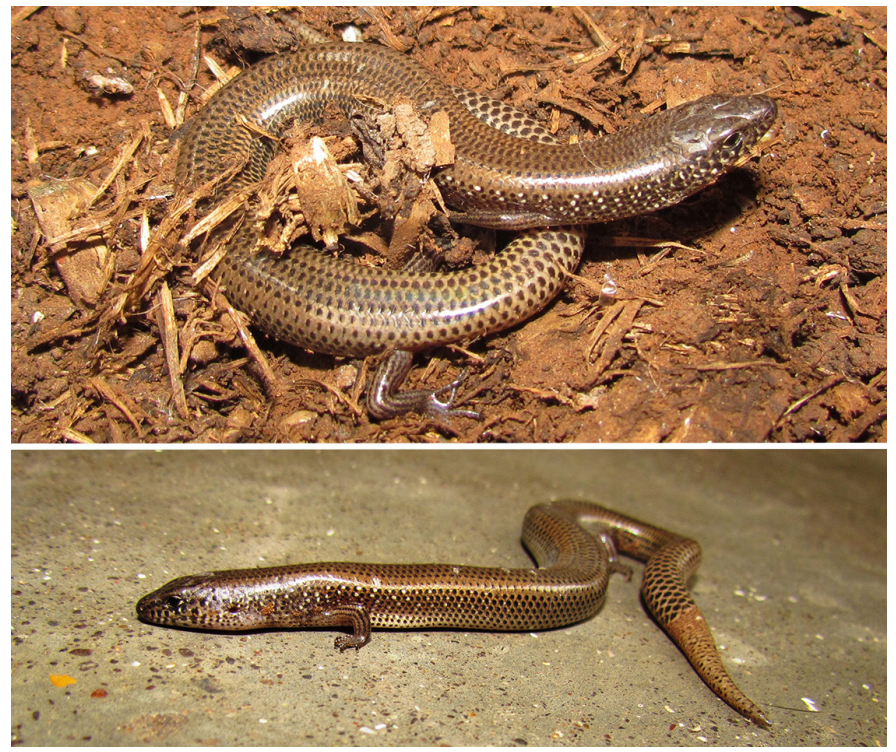

Fig. 6. Gunther's Supple Skink (Lygosoma guentheri) is an uncommon species at VNSGU. Photographs by D.S. Parmar.

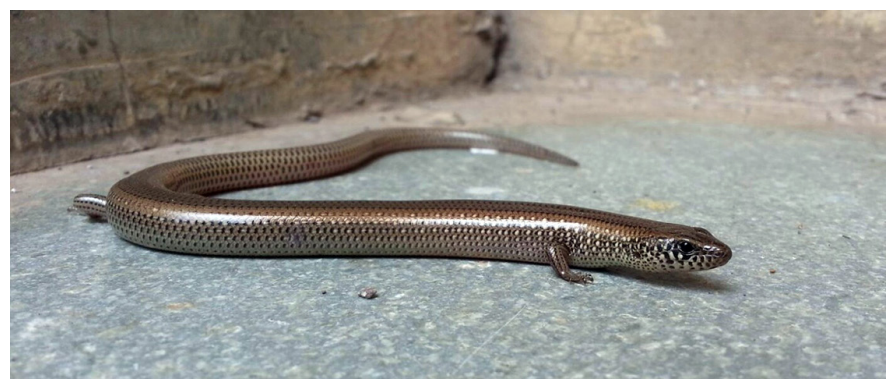

Fig. 7. This White-Spotted Supple Skink (Lygosoma albopunctata) might be the first record of the species in Gujarat. Photograph by V. Limbachiya.

These rarely seen small lizards (maximum recorded length $=255 \mathrm{~mm}$, of which $-60 \%$ is tail; Vyas 2014) with elongated snake-like bodies inhabit scrubland, agricultural areas, urban gardens, and forests, where they burrow in loose soil and under large boulders (Vyas 2014).
White-Spotted Supple Skink, Lygosoma albopunctata (Fig. 7): Vasudev P. Limbachia found one individual near the university stadium at $1534 \mathrm{~h}$ on 21 August 2018. To the best of our knowledge this is the first record of this skink in Gujarat.

\section{Squamata: Mabuyidae ${ }^{1}$}

Common Skink, Eutropis carinata (Fig. 8): We rescued one skink from the microbiology lab of the Department of Biosciences at $1452 \mathrm{~h}$ on 30 January 2018 and found another outside the lab.

This species was previously assigned to the genus Mabuya. These skinks are large (total length to $\sim 290 \mathrm{~mm}$; Daniel 1983) and active by day. These ground-dwellers occur in forests and semi-urban areas, where they often enter houses in search of prey. Females give birth to as many as eight young in one litter (Daniel 1983).

${ }^{1}$ These families sometimes are considered subfamilies of Scincidae.

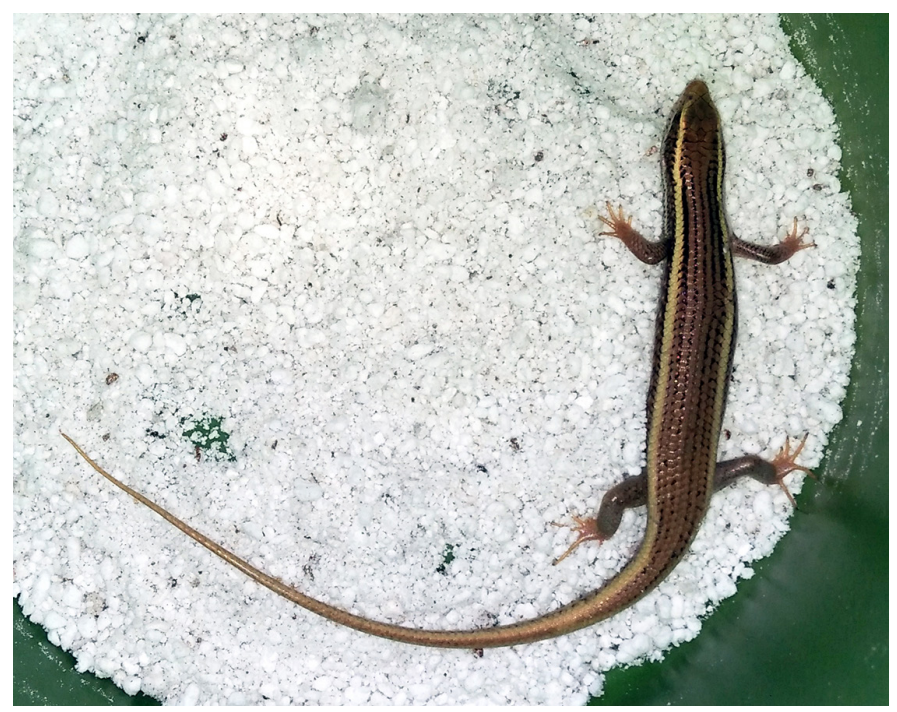

Fig. 8. A Common Skink (Eutropis carinata) rescued from the microbiology lab of the Department of Biosciences. Photograph by D.S. Parmar. 
Bronze Skink, Eutropis macularia (Fig. 9): We found a gravid female at $1545 \mathrm{~h}$ on 20 June 2018 near the convention hall. One individual found us at $2045 \mathrm{~h}$ on 28 November 2018; it had been bitten by a puppy and, despite a shoulder injury, made it to a Girnar Dormitory corridor; we released it after it recovered. At 1430 h on 9 December 2018, we saw two skinks near the lake adjacent to the Rural Studies Department. At 1110 h on 11 December 2018 we found two more skinks in the garden of the Rural Studies Department.

This species was previously assigned to the genus Mabuya. Bronze Skinks are widely distributed in India and commonly encountered on campus, where we found them in gardens and forested areas, hiding in mud crevices and walls, in grass, and on and under stones. Color and pattern are quite variable, with or without dark dorsal spots on a bronze to brown ground color. Females lay 3-4 eggs (Daniel 1983).

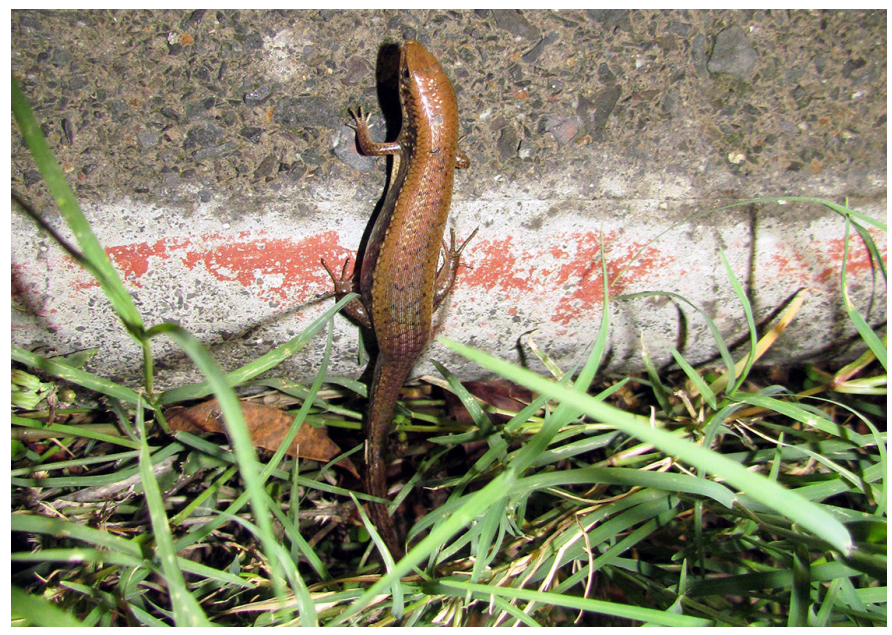

Fig. 9. A gravid female Bronze Skink (Eutropis macularia) found near the convention hall. Photograph by D.S. Parmar.

\section{REPTILES: SNAKES}

\section{Squamata: Typhlopidae}

Brahminy Blindsnake, Indotyphlops braminus (Fig. 10): We found four of these snakes; two were in the Girnar Dormitory, one near a bathroom at $0142 \mathrm{~h}$ on 18 July 2018 and the second at $2202 \mathrm{~h}$ on 31 August 2018. A third snake was in the garden near the Health Center at $2342 \mathrm{~h}$ on 3 Oct 2018 and the fourth was near the library at $2026 \mathrm{~h}$ on 13 October 2018.

The Brahminy Blindsnake is one of the smallest snakes in India (maximum recorded length $=230 \mathrm{~mm}$; Whitaker and Captain 2008). The tiny spine at the end of the blunt tail is used as an anchor when burrowing (Desai 2017). As a result of inadvertent transport with ornamental plants, these snakes now have a circum-tropical distribution (Whitaker and Captain 2008). Often associated with rootballs, snakes frequently are found in flowerpots (and are sometimes called

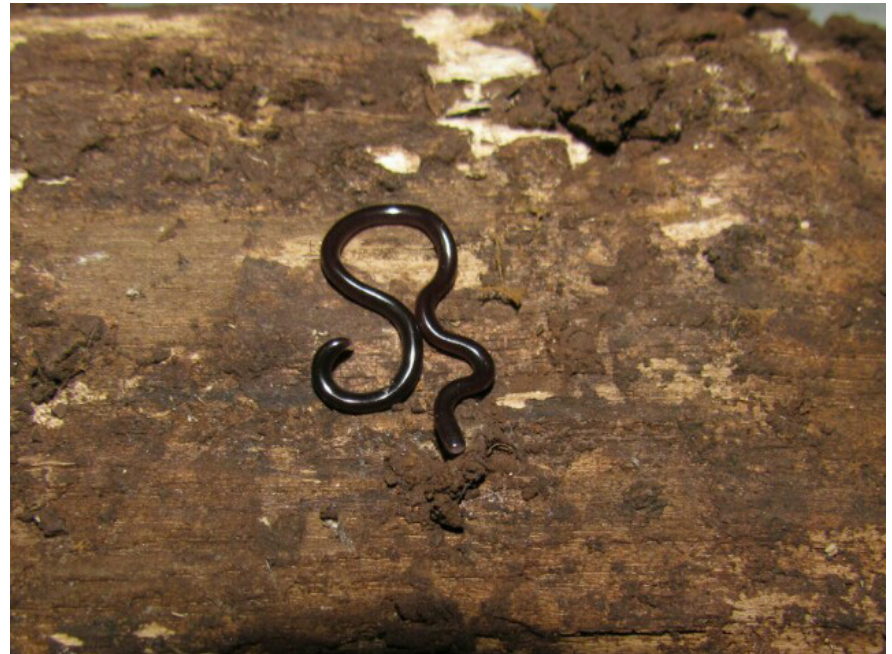

Fig. 10. The Brahminy Blindsnake (Indotyphlops braminus) is the smallest snake found at VNSGU. Photograph by D.S. Parmar.

"Flowerpot Snakes"). In natural habitats, they occur in loose soil under stones or other surface debris, in termite mounds, and in human habitations, where they are attracted by moisture (Whitaker and Captain 2008). This is the only known all-female parthenogenetic species of snake (eggs develop without fertilization). Individuals lay 2-7 eggs the size of a grain of rice (Whitaker and Captain 2008).

\section{Squamata: Erycidae ${ }^{2}$}

Common Sand Boa, Eryx conicus (Fig. 11): We rescued one large individual (total length $889 \mathrm{~mm}$ ) from the base of a boundary wall in the Sophisticated Science and Instrumentation Department at $1110 \mathrm{~h}$ on 13 October 2018. The terrain was open grassland with few trees and bushes. We found another, much smaller snake $(355 \mathrm{~mm})$ at $2040 \mathrm{~h}$ on 23 December 2018.

This species has frequently been assigned to the genus Gongylophis. These short, thick-bodied, primarily nocturnal snakes vary in dorsal ground color from yellowish white to reddish brown, dark brown, or even black (Whitaker and Captain 2008). These burrowing snakes shelter in rodent burrows and termite mounds (Whitaker and Captain 2008). Females bear 6-8 live young from May to July (Desai 2017).

\section{Squamata: Colubridae}

Trinket Snake, Coelognathus helena (Fig. 12): We found five Trinket Snakes, four were rescued and one was encountered at night during a field survey. Two were rescued from the Narmada Dormitory at 2010 h on 11 December 2017 near a bathroom and on 20 December 2017 outside the grill gate, respectively. A third individual was rescued at $2130 \mathrm{~h}$ on 11 April 2018 from a crevice in a wall around a tree between the Narmada and Ambika Dormitories. The fourth one was

${ }^{2}$ Until recently, this family was considered part of the family Boidae. 

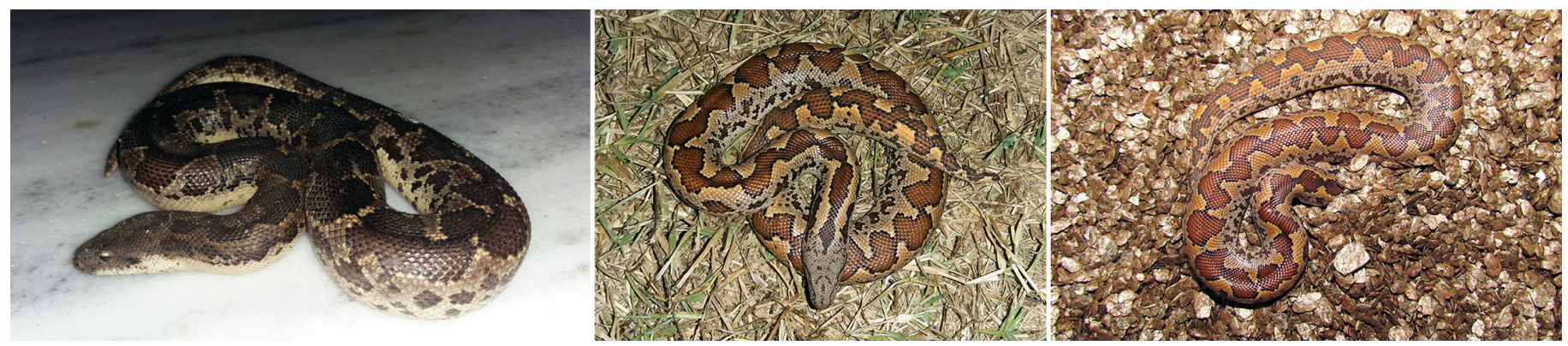

Fig. 11. A large adult Common Sand Boa (Eryx conicus; left), a juvenile (center), and an individual burrowing in the substrate while held in captivity (right). Photographs by D.S. Parmar.

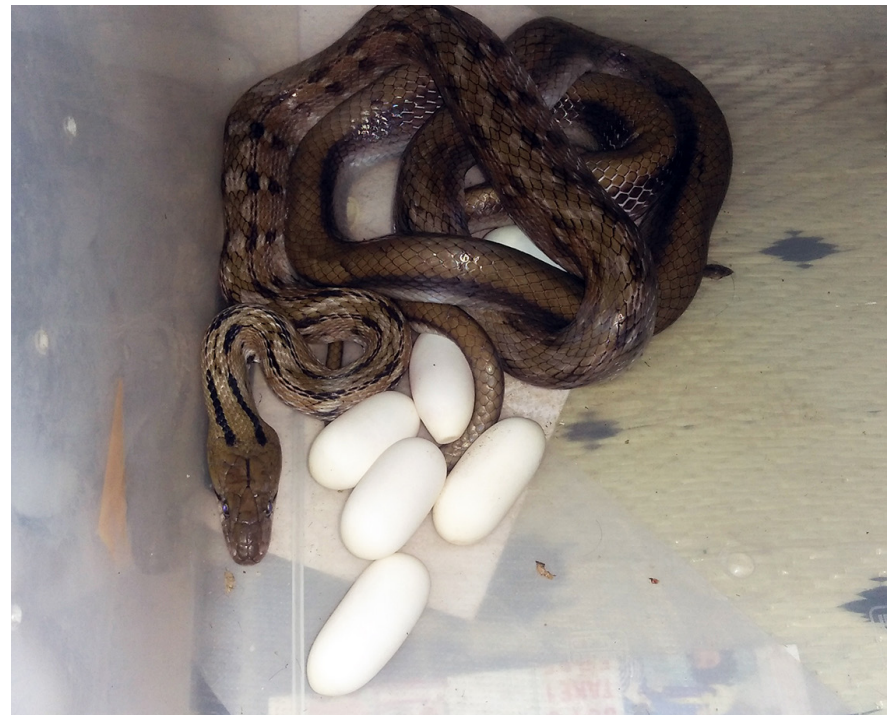

Fig. 12. A gravid female Trinket Snake (Coelognathus helena) had been searching for an egg-laying site at night; it subsequently laid ten eggs. Photograph by D.S. Parmar.

rescued from the gate of an indoor stadium at $1812 \mathrm{~h}$ on 2 June 2018. The fifth snake, a gravid female found at $1215 \mathrm{~h}$ on 12 September 2018, was the largest (total length $=1,473$ $\mathrm{mm}$, compared to the maximum recorded length of 1,676 ; Whitaker and Captain 2008). She subsequently laid 10 eggs on 15 September 2018 at $2352 \mathrm{~h}$.

These snakes are active by day and night and are frequently encountered near human habitations. Females lay elongate eggs throughout the year; in Gujarat, eggs hatch in 45-60 days (Parmar 2017).

Indian Ratsnake, Ptyas mucosa (Fig. 13): We found seven Indian Ratsnakes. The first was rescued at $1043 \mathrm{~h}$ on 20 December 2017 from the lawn near a gate into the campus. The second individual was near the track behind the gym at $1605 \mathrm{~h}$ on 3 January 2018. A staff member from the MSc (IT) Department reported the third individual. A fourth was in a newly constructed building in the English Department at 1148 h on 19 November 2018; although it escaped, SKT made a positive identification from a cellphone video. A fifth individual was initially behind the Department of Biosciences and was seen again a few days later by gardeners in the adjacent Bapalal Department, where sightings are common on roads, in backyards, and in the garden of the nearby Aquatic Department. After several failed attempts, we finally captured this crafty snake at $1350 \mathrm{~h}$ on 26 November 2018. We recorded a sixth
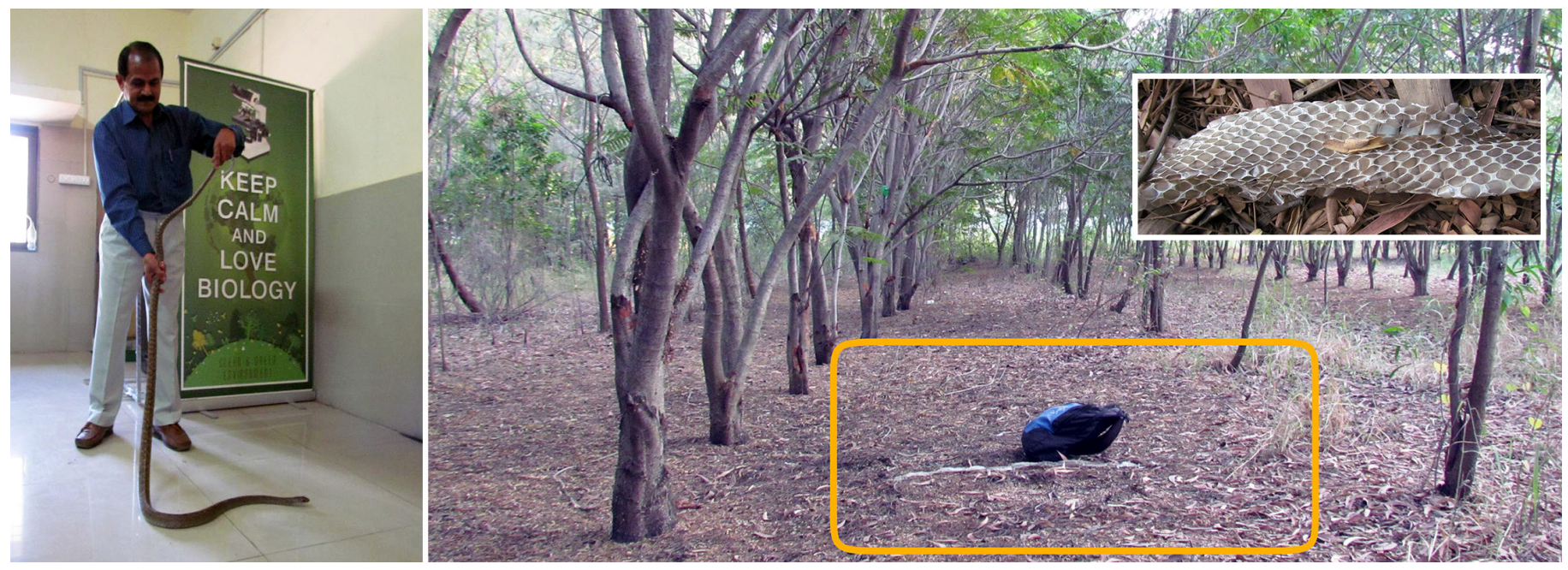

Fig. 13. Dr. S. K.Tank with an Indian Ratsnake (Ptyas mucosa), the longest non-venomous snake of India (left) and a locality for $P$. mucosa confirmed on the basis of a shed found in Nakshetra van (right and insert). Photographs by D.S. Parmar. 
snake based on a shed skin found at $1632 \mathrm{~h}$ on 9 December 2018 in Nakshetra van. The scales of the Indian Ratsnake are usually large in size and imbricate. The H.O.D of the Rural Studies Department reported the seventh individual.

Indian Ratsnakes are sighted frequently on campus during the day. Locally, these snakes are known as "Dhaman," which is Sanskrit for "long rope" (Desai 2017). The maximum recorded length of this species is 3,607 $\mathrm{mm}$ (Whitaker and Captain 2008). It lives in both mesic and xeric situations in open fields, forests, and montane and coastal areas (Whitaker and Captain 2008). This is one of the fastest snakes in India, an energetic swimmer, good tree climber, and fast on land. When provoked it compresses the body and makes growling, moaning, or mewling sounds (Daniel 1983). Females lay 6-22 eggs that hatch within 60 days (Daniel 1983; Whitaker and Captain 2008).

Indian Smooth Snake, Coronella brachyura (Fig. 14): We did not find this snake during our survey, its inclusion in this list is based on an earlier record of an individual found at 0730 h on 17 March 2006 at the M.Sc. (IT) Department. That was the first record of this rare snake in Gujarat.

This mild-tempered species is endemic to India where it hunts actively, largely during crepuscular periods (Whitaker and Captain 2008).

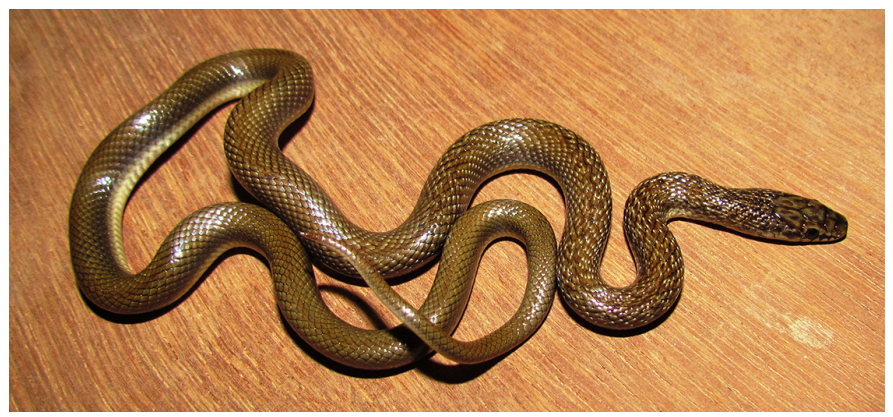

Fig. 14. First record of a rare Indian Smooth Snake (Coronella brachyura) from the M.Sc. (IT) department at VNSGU. Photograph by D.S. Parmar.

Common Kukri Snake, Oligodon arnensis (Fig. 15): We found four of these snakes. The first was a juvenile found at $0944 \mathrm{~h}$ on 19 January 2018 at the gate of the Narmada Dormitory. The second was an adult found at $1946 \mathrm{~h}$ on 9 Oct 2018 on the road outside the library. The third, encountered during a field survey, was on a narrow foot path between the garden and the lake opposite the Fine Arts Department; the lake is fenced and the snake was beneath plants at the border of the fencing. A colleague found the fourth individual at $2154 \mathrm{~h}$ on 22 September 2018.

Common Kukri Snakes are primarily nocturnal and crepuscular. They often are encountered near human habita-

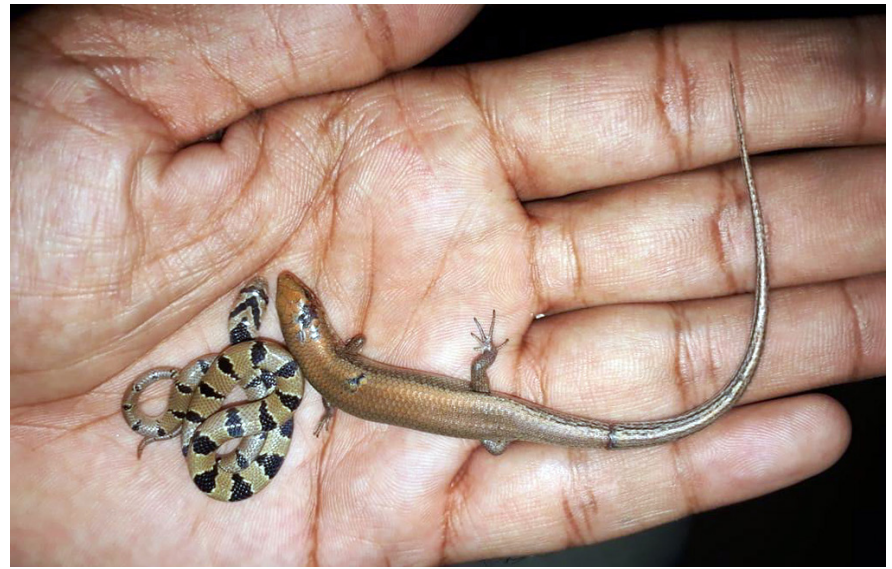

Fig. 15. A Common Kukri Snake (Oligodon arnensis) and a Bronze Skink (Eutropis macularia) that had been bitten by a dog; both were found during the same night-time survey. Photograph by D.G. Gamit and D.S. Parmar.

tions, where they frequent gardens, houses, apartments, termite mounds, crevices, masonry, low bushes or tree holes, and other refugia (Whitaker and Captain 2008). Females lay 2-9 remarkably long eggs (Whitaker and Captain 2008).

Common Wolfsnake, Lycodon aulicus (Fig. 16): We found two individuals, one was rescued from the Vice-chancellor's residence at $2210 \mathrm{~h}$ on 4 December 2017. The other was on the lower trunk of a Peepal Tree (Ficus religiosa) opposite the university cafeteria at $2145 \mathrm{~h}$ on 24 August 2018. An earlier record from a professor's quarters was at a ground-floor window during a monsoon.

Nonvenomous and uncommon on the VNSGU campus, Common Wolfsnakes vary considerably in dorsal coloration, with a light to dark glossy brown, dark gray, or black ground color punctuated with yellow or whitish crossbars (Desai 2017; Whitaker and Captain 2008). Frequently found near

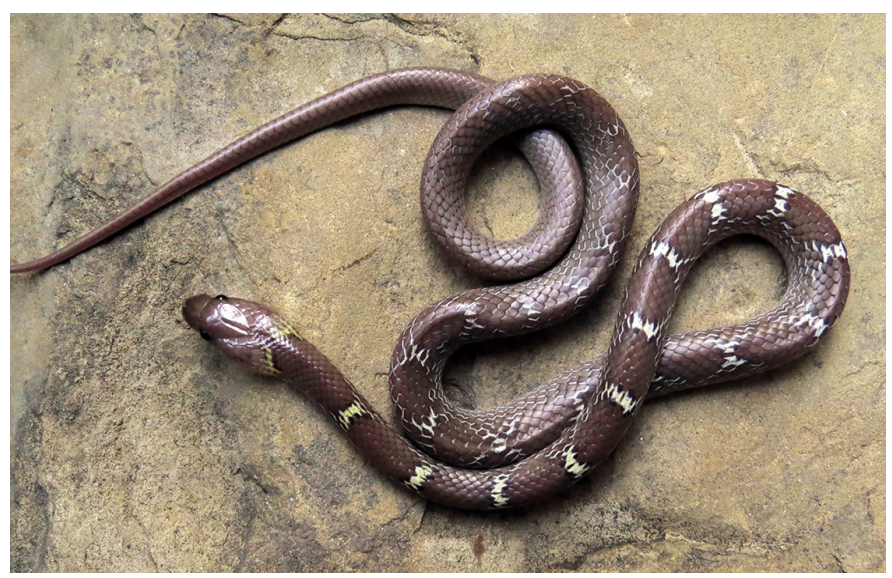

Fig. 16. The Common Wolfsnake (Lycodon aulicus) is frequently encountered in Surat City but is uncommon on the VNSGU campus; this individual was found during a field survey at night. Photograph by M.H. Patel. 
or in human habitations, these excellent climbers also occupy hollow trees, stone piles, caves, and wells. Females lay 4-11 eggs (Daniel 1983).

\section{Squamata: Natricidae ${ }^{3}$}

Checkered Keelback, Xenochrophis piscator (Fig. 17): We recorded five individuals. The first, with some unusual pinkish markings, was rescued near the compound wall at the main gate at $1615 \mathrm{~h}$ on 11 December 2017. The second was resting beneath a stone at the border of the fenced lake at $1639 \mathrm{~h}$ on 25 January 2018. We were not able to capture this individual for data collection as it quickly entered the lake. We rescued a third snake from a bathroom of the Ambika Dormitory at 1305 h on 14 July 2018. The fourth individual was crossing a road and entering the grounds of the Department of Fine Arts at $2147 \mathrm{~h}$ on 24 August 2018. The fifth was at the Economics Department at $1400 \mathrm{~h}$ on 28 August 2018. The last snake regurgitated an Indian Bullfrog (Hoplobatrachus tigerinus).

Checkered Keelbacks are quite variable in color, pattern, and some aspects of morphology (Parmar 2018a). Dorsal ground colors range from pink or reddish, dull olive-green

${ }^{3}$ This family sometimes is considered a subfamily of Colubridae (sensu lato). and olive-brown to pale or golden yellow and even white. These semi-aquatic snakes are closely associated with streams, lakes, ponds, rivers, and paddy fields, where they are active by both day and night. Snakes of both sexes are frequent roadkills during the rainy season, and many individuals are encountered on roads at night. This species demonstrates parental care, females staying with their clutches of 8-91 eggs during the incubation period of 37-60 days (Daniel 1983; Parmar 2018a). A record number of 120 eggs was laid by a $X$. piscator in the Anand District of Gujarat (Parmar 2018a).

Buff-striped Keelback, Amphiesma stolatum (Fig. 18): We found 13 individuals during the monsoon season in gardens, on roads and in parking lots, in departments near the cafeteria, near the gate, and near the stadium - almost everywhere on campus. Six individuals were at the Bapalal Department at $0912 \mathrm{~h}$ on 5 July 2018 . One was on a wet road near the Human Resources Department at 0031 h on 21 July 2018. The gate keeper at the gate near the convention hall found a snake on 30 August 2018. One gravid female with eggs was found dead on the road adjacent to the Aquatic Department at $1512 \mathrm{~h}$ on 20 September 2018. Another road-killed individual was near the Department of Computer Sciences at
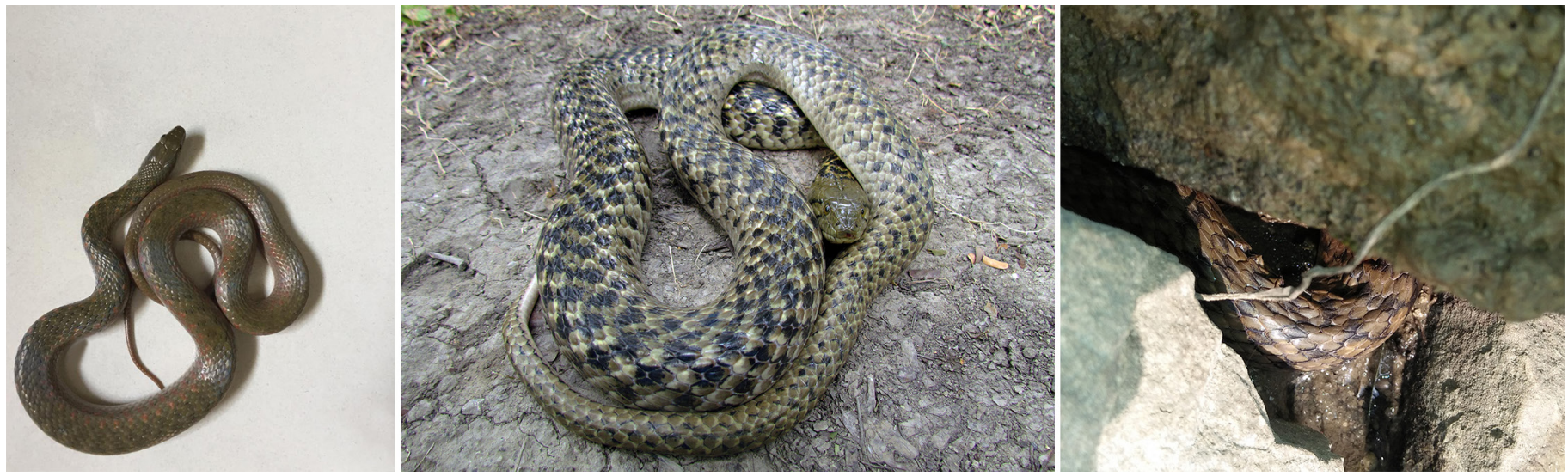

Fig. 17. A Checkered Keelback (Xenochrophis piscator) with pinkish spots rescued from the VNSGU campus (left), a more typically colored individual (center), and an individual found beneath a stone (right). Photographs by Dr. S.K. Tank (left, right) and D.S. Parmar (center).
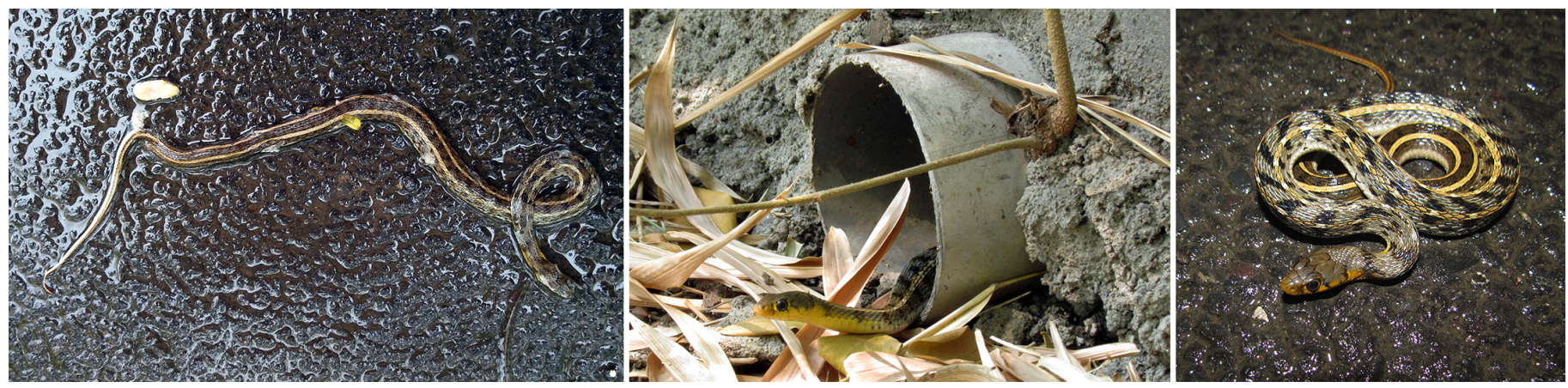

Fig. 18. A gravid female Buff-striped Keelback (Amphiesma stolatum) dead on the road with a fully developed egg (left), a visual encounter of a snake in natural habitat (center), and an individual on a wet road at night indicates that this species is not strictly diurnal (right). Photographs by D.S. Parmar. 
$1306 \mathrm{~h}$ on 17 September 2018. Still another roadkill was near the Economics Department at $2311 \mathrm{~h}$ on 28 September. We found an individual at $2343 \mathrm{~h}$ on 1 October 2018 near the Department of Biosciences and another snake at $1213 \mathrm{~h}$ on 26 October 2018.

These snakes are known to aestivate and hibernate and are thus encountered most frequently during the monsoons. Buff-striped Keelbacks are reported to be diurnal (Whitaker and Captain 2004, 2008) but, during our survey, we found active live individuals and fresh roadkills at night. These snakes frequent paddy fields, nurseries, ponds, marshes, and lakes, but also gardens, grassy and bushy areas, forests, and human habitations inevitably near water (Daniel 1983; Whitaker and Captain 2008; Desai 2017). Females are larger than males and lay 5-15 eggs at a time (Whitaker and Captain 2008).

Green Keelback, Macropisthodon plumbicolor (Fig. 19): At 1850 h on 10 April 2018 we recovered two hatchlings from Nakshetra van (Parmar 2018b). Earlier records from 2010 are of adults from a professor's quarters.

Largely nocturnal but sometimes crepuscular, Green Keelbacks are relatively rare in the area. These snakes occur in a wide variety of natural and altered habitats, including grasslands, areas of low vegetation, forests, gardens, and urban areas, often near bodies of water where they frequently seek shelter in rock piles. Egg laying has been reported in April (Vyas1993) and January (Parmar 2018b). Females lay as many as 18 eggs, which hatch in 60-62 days (Parmar 2018b).

\section{Squamata: Elapidae}

Common Krait, Bungarus caeruleus (Fig. 20): We found no Common Kraits during this survey, but earlier rescue records

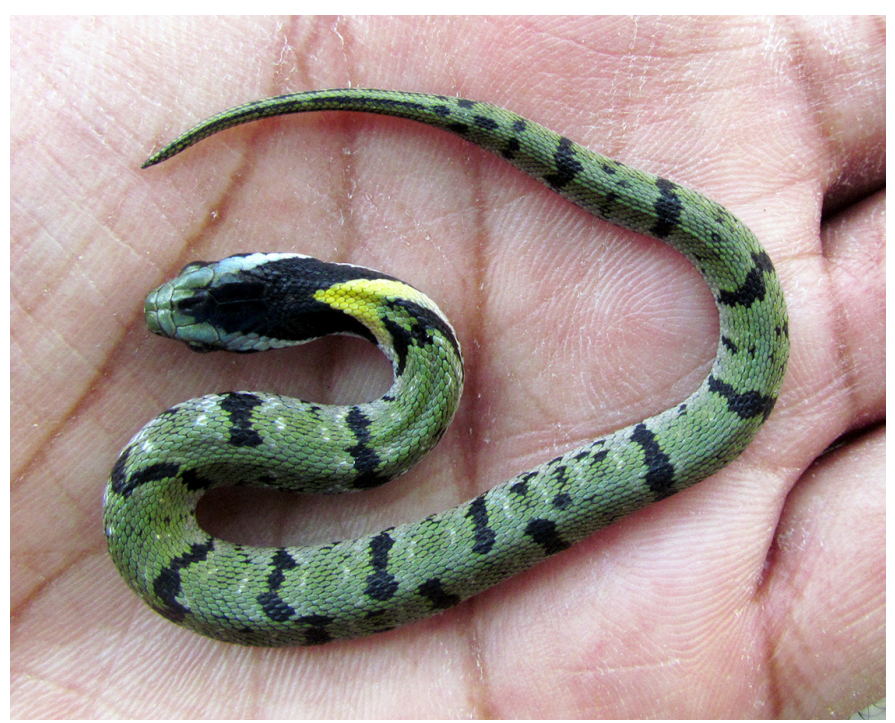

Fig. 19. A juvenile Green Keelback (Macropisthodon plumbicolor) found during a field survey at night. Photograph by D.S. Parmar.

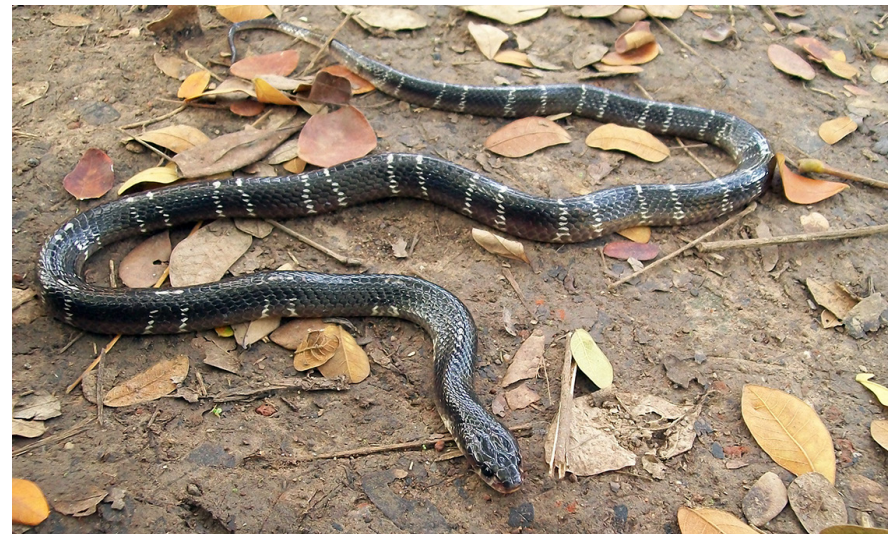

Fig. 20. Common Kraits (Bungarus caeruleus) feed mainly on other snakes. Photograph by D.S. Parmar.

document snakes taken from the Narmada Dormitory, professor's quarters, and the Biotech Department. At $2130 \mathrm{~h}$ on 5 April 2011, we found a dead male in the parking area by the gate near the Narmada Dormitory. A juvenile was rescued from a professor's quarters at $2300 \mathrm{~h}$ in August 2012 during heavy rainfall. Another rescue involved an adult from a bathroom on the first floor of the Biotech Department at $1045 \mathrm{~h}$ in October 2012.

The maximum recorded length for this venomous species is $1,750 \mathrm{~mm}$ (Whitaker and Captain 2008). The venom of the Common Krait is the most potent among India's four venomous terrestrial snakes (Whitaker and Captain 2008). Kraits are rarely encountered at VNSGU, in part due to their nocturnal activity. Common Kraits feed mainly on other snakes and are known to be cannibalistic. Females lays 6-15 eggs (Daniel 1983).

Indian Cobra, Naja naja (Fig. 21): An Indian Cobra was rescued from under small plants at the Satpuda Dormitory at $2130 \mathrm{~h}$ on 23 April 2018 and another was rescued at 1527 h on 14 September 2018 from the M.Sc. (IT) Department, where it was resting beneath the last bench in a classroom. A third cobra was seen in the Botanical Gardens behind the Bapalal Department. Dr. Somani, the H.O.D of the Rural Studies Department, informed us that a cobra had laid eggs and that they all had hatched; hatchlings were found under the table in the office and also in classrooms and nearby gardens.

The recorded maximum length of the species is 2,200 $\mathrm{mm}$ (Whitaker and Captain 2008). These snakes are active by day and night and thrive in many habitats, including open jungles, cultivated land, and populated areas where old masonry constructions provide ideal refugia. These strong swimmers are frequently found near water (Daniel 1983). Females lay 12-30 white leathery eggs between March and July in termite mounds, hollow trees, caves, and other sheltered locations; eggs hatch in 48-69 days (Daniel 1983; Whitaker and Captain 2008). 


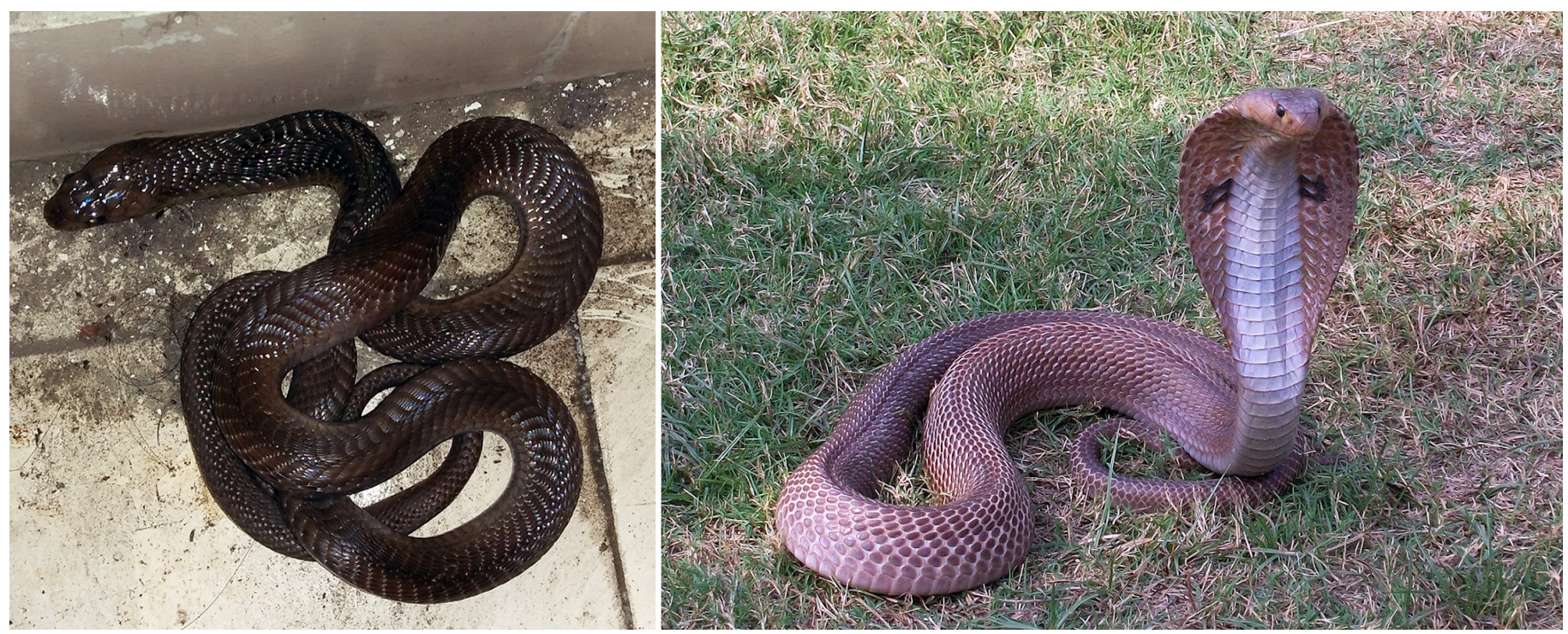

Fig. 21. An Indian Cobra (Naja naja) found near the last bench in a classroom of the M.Sc. (IT) Department (left) and an adult hooding (right). Photographs by D.S. Parmar.

\section{Squamata: Viperidae}

Russell's Viper, Daboia russelii (Fig. 22): We encountered eleven Russell's Vipers during this survey. At 1545 h on 5 February 2018, an adult that was about to shed was rescued from the M.Sc. (IT) Department. An individual was in grass near the Chemistry Department at 1803 h on 13 February 2018. At 1339 h on 3 May 2018, we rescued another individual. A dead male that had been killed by laborers had been living in a temporary hut beside the indoor stadium; it was retrieved at $1752 \mathrm{~h}$ on 11 July 2018. At $2034 \mathrm{~h}$ on 21 August 2018, we rescued a juvenile from an ATM. A subadult was seen disappearing into the grass near Nakshetra van at $1514 \mathrm{~h}$ on 25 August 2018. At $1426 \mathrm{~h}$ on 5 September 2018, we rescued a snake that was observed entering the Bapalal Department. At 1547 h on 15 November 2018, we rescued a subadult with a telltale bulge indicating that it had recently consumed a prey item; it was hiding behind plants in the green house at the Bapalal Department. This snake took seven days to digest its prey before it was released into natural habitat. Another individual was rescued earlier in 2017 and the H.O.D. of the Rural Studies Department informed us that two individuals were sighted frequently in a nearby grassy area. One was often seen basking and another was hiding beneath fallen leaves.

Russell's Vipers are usually nocturnal. They occupy open grasslands, scrub jungle, forests, thorny hedgerows, mangrove stands, and rocky areas. Females bear 6-63 live young from May to July (Whitaker and Captain 2008). In the Solapur District of Maharashtra, a female is reported to have given birth to 96 young in June (Habib and Cheda 2010).

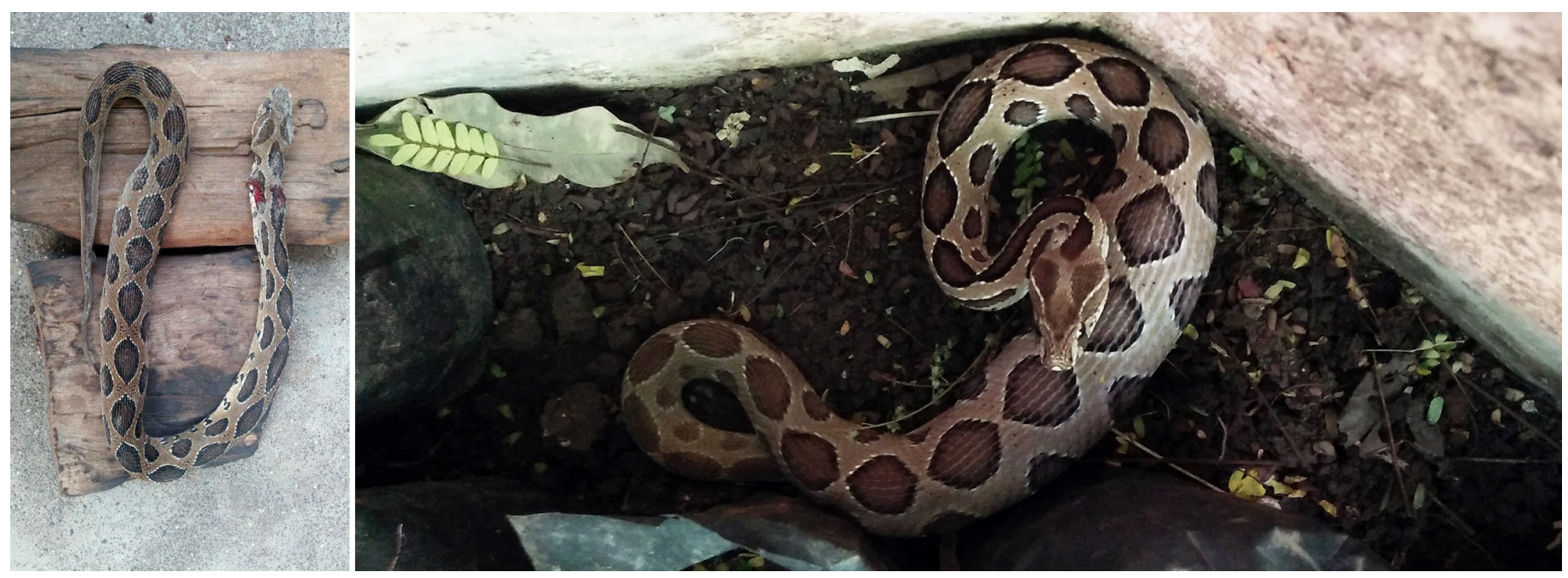

Fig. 22. An adult male Russell's Viper (Daboia russelii) killed by laborers near the indoor stadium on the VNSGU campus (left) and an adult with a telltale bulge indicative of a recent meal (right). Photographs by D.S. Parmar. 
Saw-scaled Viper, Echis carinatus (Fig. 23): Venomous and uncommon. A total of four individuals were reported, including two earlier records. One was found during lawn mowing in the garden opposite the Department of Biosciences on 6 June 2018 at $1044 \mathrm{~h}$. Another was spotted on the road by a security guard on night duty and rescued from the Computer Science Department on 7 October 2018 at 2234 h. Earlier records are from the Fine Arts Department in 2016 and the M.Sc. (IT) Department in 2011.

Mainly nocturnal, Saw-scaled Vipers occur in open dry, sandy or rocky terrain in the plains and hills and also in open rocky region with heavy rainfall (Desai 2017; Whitaker and Captain 2008). When alarmed they rub saw-edged scales together to make a rasping sound and will strike quickly when provoked. Females bear from 4-8 live young from April to August (Whitaker and Captain 2008).

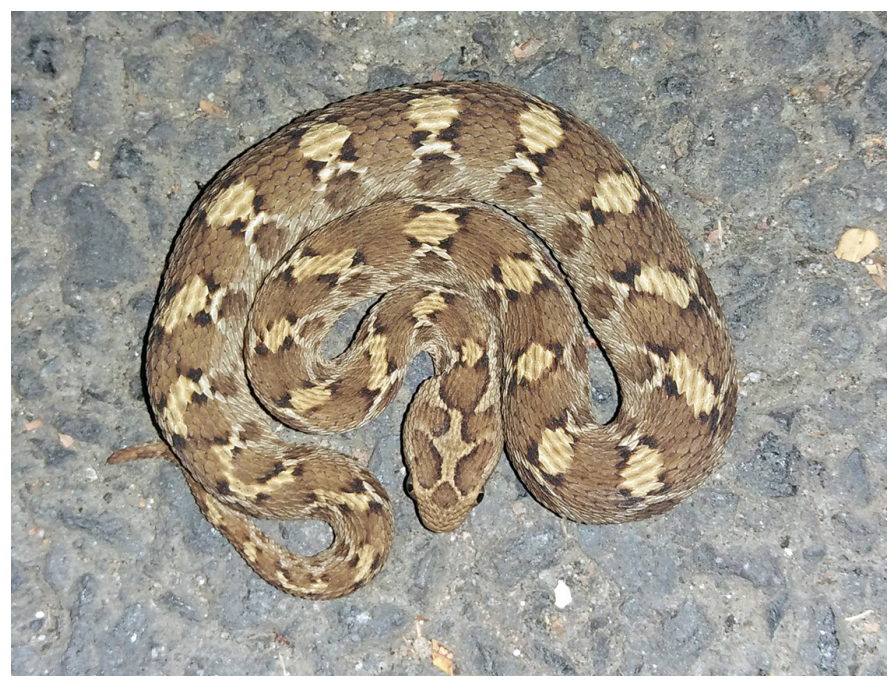

Fig. 23. This Saw-scaled Viper (Echis carinatus) was found at night by a security guard who called the snake rescue. Photograph by D.S. Parmar.

\section{AMPHIBIANS: FROGS AND TOADS}

\section{Anura: Bufonidae}

Common Asian Toad, Duttaphrynus melanostictus (Fig. 24): These toads are abundant on the VSNGU campus, where they are ubiquitous at night. We recorded individuals from the gardens of the Main Building, the Bioscience Department, the Fine Arts Department, the Human Resources Department, the Chemistry Department, the Rural Studies Department, dormitories, ATMs, the Health Center, the gym, the Convention Hall, the stadium, and near both main gates.

Common Asian Toads grow to $200 \mathrm{~mm}$ in length. They breed during monsoons and the larvae are found in still and slow-moving water (van Dijk et al. 2004).

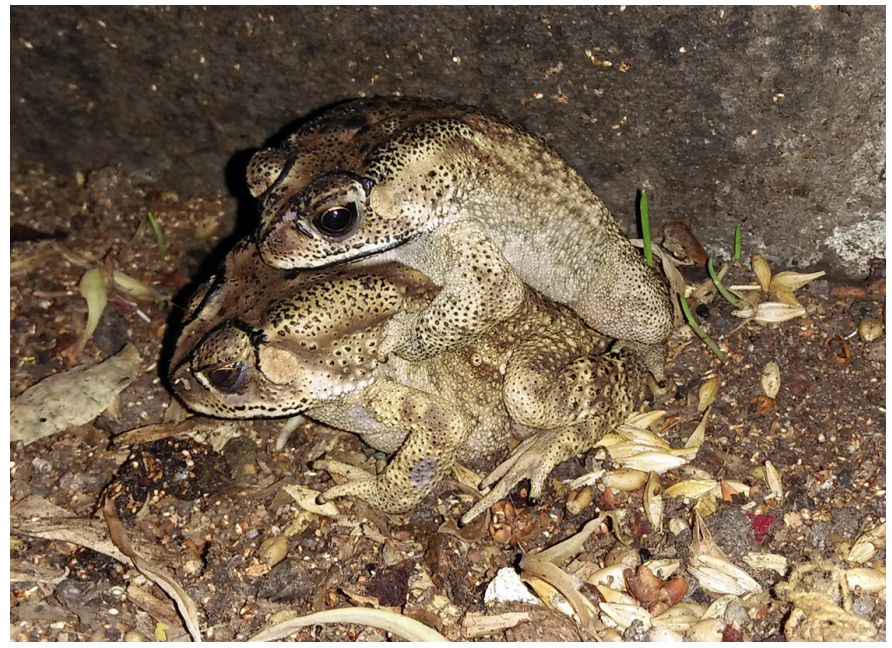

Fig. 24. Common Asian Toads (Duttaphrynus melanostictus) in amplexus. Photograph by D.S. Parmar.

Schneider's Dwarf Toad, Duttaphrynus scaber (Fig. 25): These toads are frequently encountered during rainy nights. At 1251 h on 16 April 2018, we found a small toad on the road near the Girnar Men's Dormitory. To the best of our knowledge this is the first record of this toad in the Surat District. On a rainy night, another toad was calling.

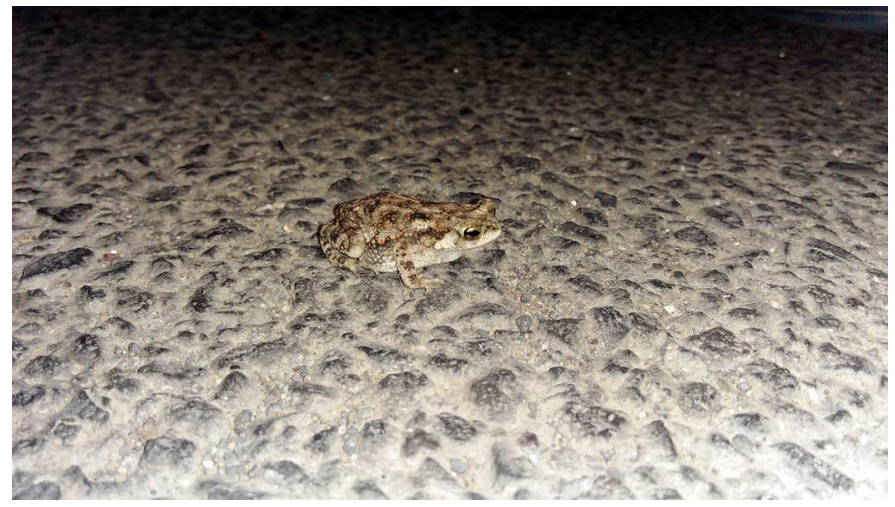

Fig. 25. A Schneider's Dwarf Toad (Duttaphrynus scaber) found during a field survey at night. Photograph by D.S. Parmar.

These toads occur in peninsular India and Sri Lanka (Frost 2014) where they occupy various habitats that include wet evergreen tropical forest, tropical dry forest, dry scrublands, grasslands, coastal marshes, and cultivated areas. Eggs are laid in stagnant waters (Dutta and Manamendra-Arachchi 2004; Daniels 2005). In parts of its range, this species is seriously threatened by habitat loss caused by deforestation, pollution, and urbanization (Dutta and Manamendra-Arachchi 2004).

Indian Marbled Toad, Duttaphrynus stomaticus (Fig. 26): We found one individual at $1902 \mathrm{~h}$ on 5 December 2018 in the garden opposite the main building. This species is reported here for the first time from the Surat District. 


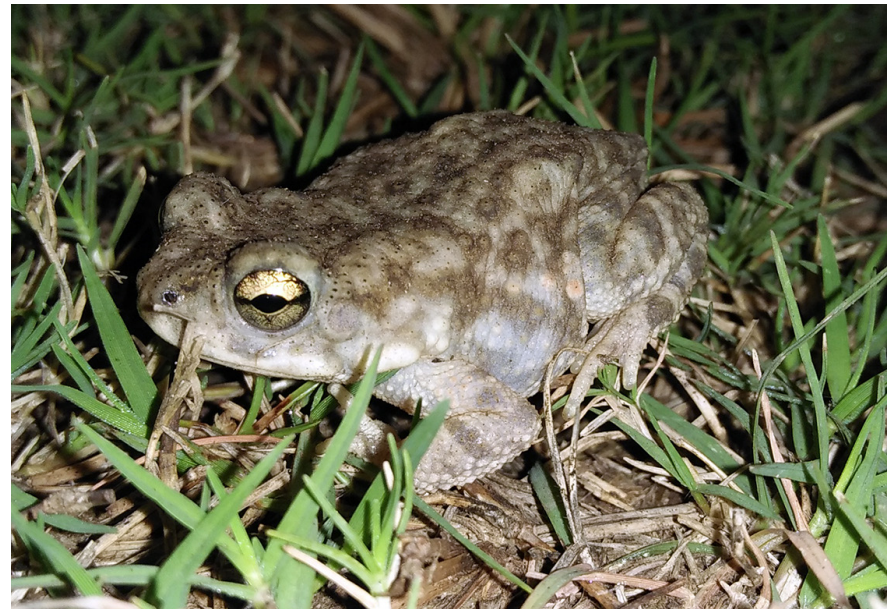

Fig. 26. This Indian Marbled Toad (Duttaphrynus stomaticus) is the first record from the Surat District. Photograph by D.S. Parmar.

These toads are common in floodplains but reach elevations to about $2,000 \mathrm{~m}$. They are tolerant of varying climatic conditions, including those of dry semideserts. Indian Marbled Toads are essentially nocturnal but are mostly diurnal during the breeding season when they congregate and lay eggs mostly in temporary bodies of water (Khan 2002).

\section{Anura: Dicroglossidae}

Long-legged Cricket Frog, Minervarya syhadrensis (Fig. 27): We found one individual behind the cafeteria at 1223 h on 30 December 2017 and a second frog was located many times in and around the lake opposite the Fine Arts Department. At 2407 h on 9 January 2018, while collecting frogs to feed snakes, we found another $M$. sahyadrensis.

Adults are 31-35 mm in length (Daniels 2005). Until recently, this species was assigned to the genus Fejervarya. These frogs are very similar to Fejervarya limnocharis but can be easily distinguished by the bleating sheep-like call and white upper lip with black crossbars (Daniels 2005).

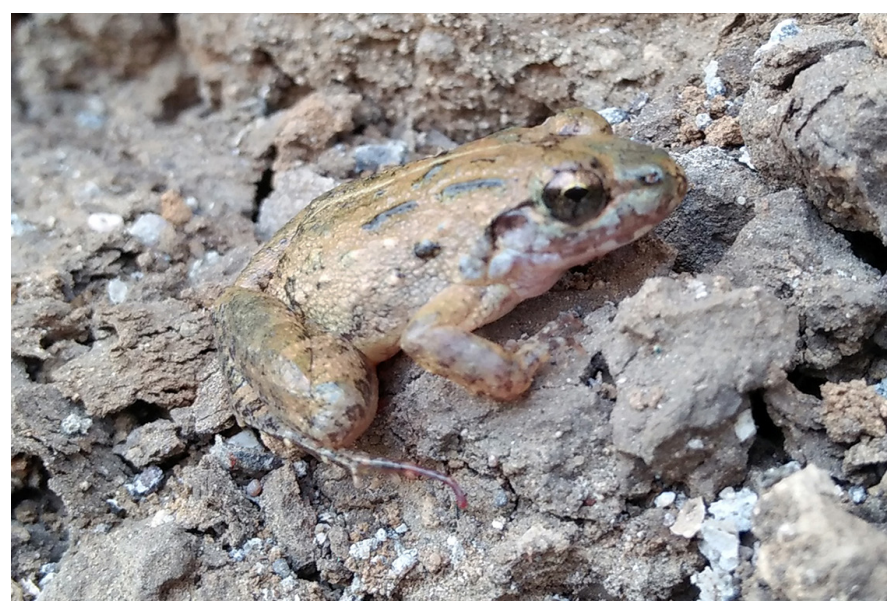

Fig. 27. A Long-legged Cricket Frog (Minervarya syhadrensis) found during the day. Photograph by D.S. Parmar.
Indian Cricket Frog, Fejervarya limnocharis (Fig. 28): These frogs are abundant on the VNSGU campus, especially around the lake and garden opposite the Fine Arts Department.

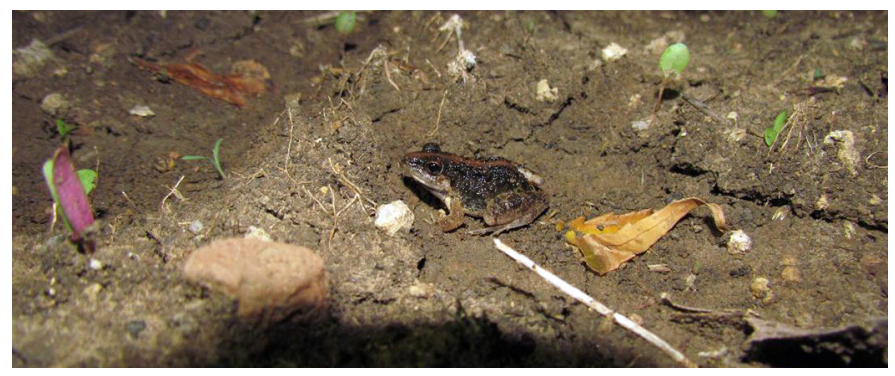

Fig. 28. Indian Cricket Frogs (Fejervarya limnocharis) are abundant on the VNSGU campus. Photograph by D.S. Parmar.

Indian Cricket Frogs can grow to $64 \mathrm{~mm}$ but those in peninsular India rarely exceed $30 \mathrm{~mm}$; females are larger than males. These frogs occur in wetlands and damp meadows and breeding occurs after the first rains (Daniels 2005).

Indian Bullfrog, Hoplobatrachus tigerinus (Fig. 29): The Indian Bullfrog is the largest and most common frog in India. It is ubiquitous on the VNSGU campus, where we found individuals in grassy areas, gardens, along road sides, and in buildings. We found two amplected pairs in the wet grass opposite the Girnar Dormitory at $1318 \mathrm{~h}$ and $1356 \mathrm{~h}$ on 3 July 2018.

Adults can reach $160 \mathrm{~mm}$. These frogs are voracious and will eat anything they can fit in their mouths; they are known to prey on other frogs but have also been recorded eating a juvenile Russell's Viper and a baby Peacock in Surat City.

\section{Anura: Microhylidae}

Ornate Narrow-mouthed Frog, Microbyla ornata (Fig. 30): We found eight individuals during monsoons at night. Two were in grassy areas near the Girnar Dormitory and on the grounds of the main administrative building. At $0003 \mathrm{~h}$ on 30 June 2018, six frogs were at the lake opposite the Fine Arts Department.

Adults reach $25 \mathrm{~mm}$ in length (Daniels 2005). These frogs breed starting with the first rains in June through September.

\section{Discussion}

The VNSGU campus supports a rich and diversified herpetofauna. Grasslands, gardens, lakes, and wooded areas provide habitat for reptiles and amphibians. Among the 30 species recorded herein are records of uncommon and rare species, including the first records from the Surat District of Gujarat for species like the White-spotted Supple Skink, Indian 

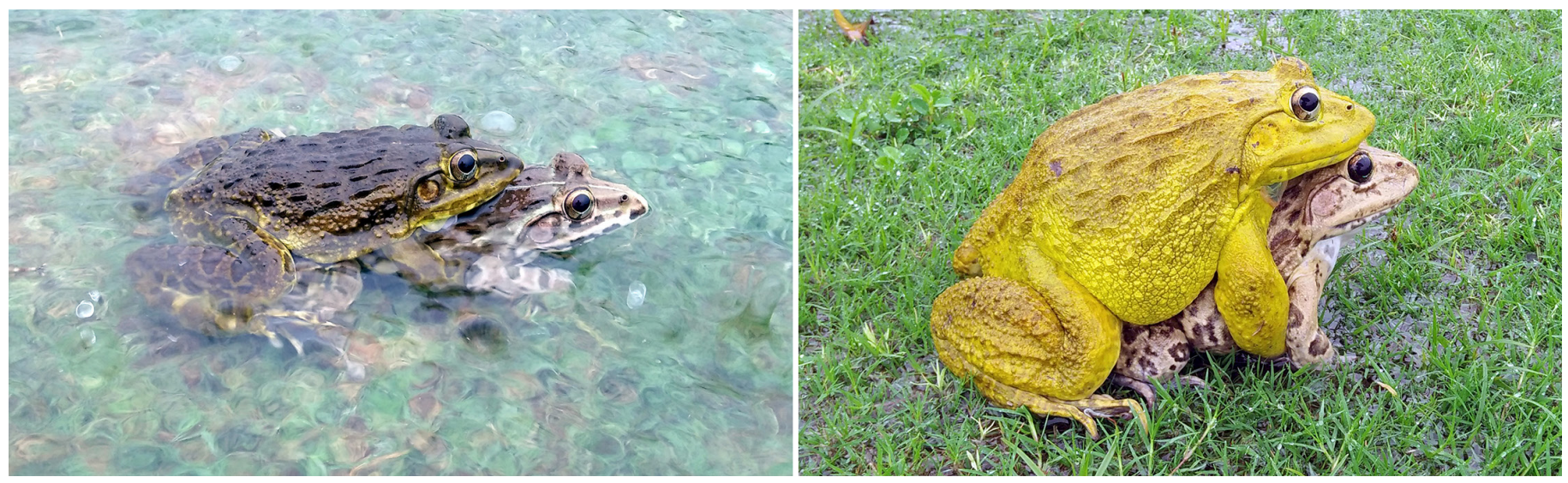

Fig. 29. Two pairs of Indian Bullfrogs (Hoplobatrachus tigerinus) in amplexus. Photographs by D.S. Parmar.

Smooth Snake, Schneider's Dwarf Toad, Indian Marbled Toad, Long-legged Cricket Frog, and Ornate Narrowmouthed Frog. Furthermore, additional species not included in this report are found occasionally in adjacent areas and

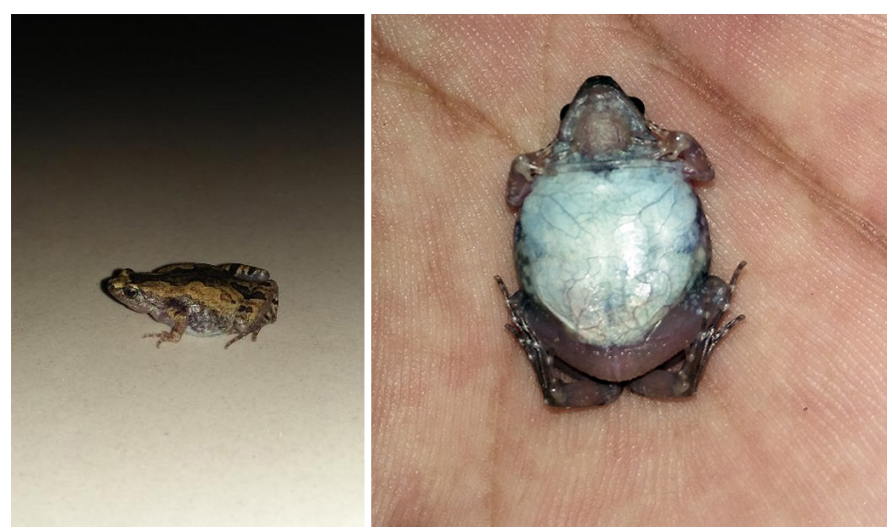

Fig. 30. An Ornate Narrow-mouthed Frog (Microhyla ornata) found at night (left) and the venter of the same individual (right). Photographs by D.S. Parmar. likely occur on campus grounds. Notable among these is the Common Vinesnake (Ahaetulla nasuta; Fig 31).

We also recorded direct and indirect threats affecting the reptiles and amphibians of VNSGU. Road mortality is an increasing threat to biodiversity worldwide. For reptiles and amphibians, roadkills are especially common during the monsoon season (Fig. 32), which generally coincides with the breeding seasons of many species. In addition, snakes are frequently killed by lawn mowers, ongoing new construction destroys microhabitats, and the open burning of wastes (including plastics) renders affected areas uninhabitable by herpetofauna. Nevertheless, VNSGU's heritage of biodiversity can be protected by continuing to raise awareness of land use practices, conserving for example, spaces that may seem available for construction but actually provide habitat for wildlife and plants. One positive development at VNSGU is that killing snakes is rare. Most people prefer to call the snake rescue. An Eco-club in the Department of Biosciences also supports a Snake Awareness Program (SAP), anti-plastic campaigns, tree planting, active encouragement of safe driving to avoid roadkills, efforts to

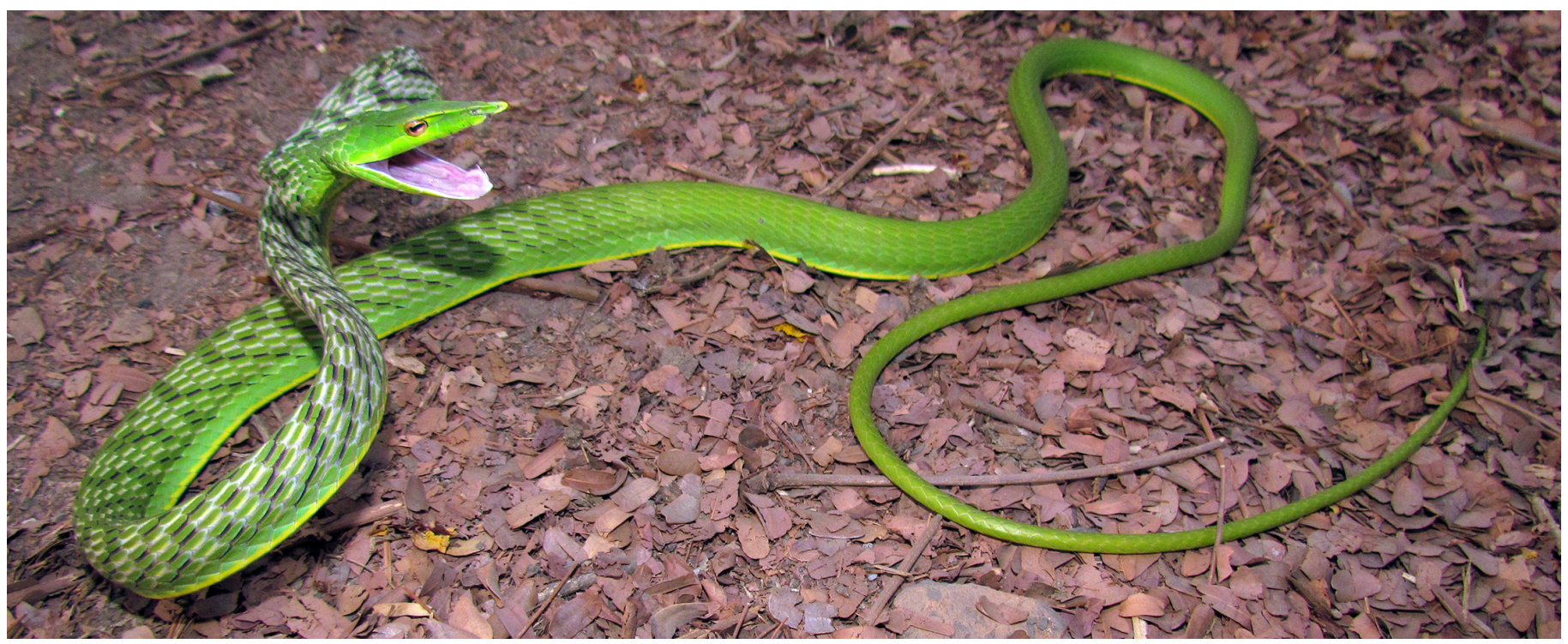

Fig. 31. A Common Vinesnake (Ahaetulla nasuta) rescued from a tree just outside the VNSGU campus. Photograph by D.S. Parmar. 


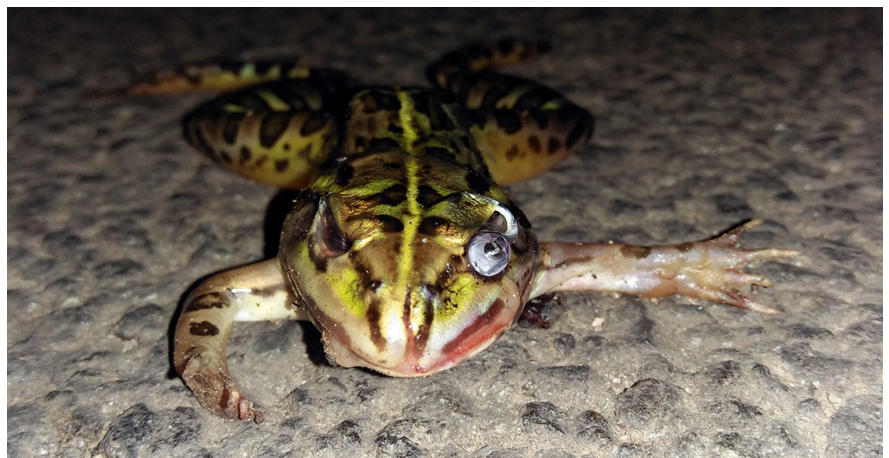

Fig. 32. A road-killed Indian Bullfrog (Hoplobatrachus tigerinus) found on the VNSGU campus. Photograph by D.S. Parmar.

sustain microhabitats by not burning or removing leaf litter, termite mounds, and other types of cover objects, and projects like this herpetofaunal assessment, all in an effort to promote the conservation of our environment. We also appeal to all educational institutions to raise awareness among staff and students and solicit their help to preserve remaining green spaces and the natural communities they support.

\section{Acknowledgements}

We thank Divyesh G. Gamit, Mahamad Jahid A. Patel, Moksh H. Patel, Nirav A. Chaudhari, Piyush Kumar, P. Jaydip, R. Vasava, Shreyas G. Chaudhari, Vasudev P. Limbachiya, and Vrajesh D. Patel for logistical support and help in rescue and field surveys. We also are thankful to Dr. Somani, Mehul K. Modi, and others who provided information through personal communications.

\section{Literature Cited}

Aengals, R., S.V.M. Kumar, and M.J. Palot. 2012. Updated Checklist of Indian Reptiles. (http://www.lacertilia.de/AS/Bibliografie/BIB_6715.pdf).

AmphibiaWeb. 2019. University of California, Berkeley, California. (https:// amphibiaweb.org).

Boulenger, G.A. 1890. The Fauna of British India, including Ceylon and Burma. Reptilia and Batrachia. Taylor and Francis, London.

Boulenger, G.A. 1920. A Monograph of the South Asian, Papuan, Malaysian and Australian Frogs of the Genus Rana. Records of Indian Museum, Calcutta.

Daniel, J.C. 1963a. Field guide to amphibian of western India. Part-I. Journal of the Bombay Natural History Society 60: 415-438.

Daniel, J.C. 1963b. Field guide to amphibian of western India. Part-II. Journal of the Bombay Natural History Society 60: 690-702.

Daniel, J.C. 1975. Field guide to amphibian of western India. Part-III. Journal of the Bombay Natural History Society 72: 506-522.

Daniel, J.C. 1983. The Book of Indian Reptiles. Bombay Natural History Society, Bombay, India.

Daniel, J.C. 2002. The Book of Indian Reptiles and Amphibians. Bombay Natural History Society, Bombay, India.

Daniel, J.C. and E.M. Shull 1963. A list of the reptiles and amphibians of Surat, Dangs, South Gujarat. Journal of the Bombay Natural History Society 60: 737-743.

Daniels, R.J. 1997a. A field guide to the frogs and toads of the Western Ghats, India. Part I. Cobra 27: 1-25.

Daniels, R.J. 1997b. A field guide to the frogs and toads of the Western Ghats, India. Part II. Cobra 28: 1-24.
Daniels, R.J. 1997c. A field guide to the frogs and toads of the Western Ghats, India. Part III. Cobra 29: 1-13.

Daniels, R.J. 2005. Amphibians of Peninsular India. Universities Press, Hyderabad, Telangana, India.

Das, I. 1994. The reptiles of South Asia, checklist and distribution summary. Hamadryad 19: 15-40.

Das, I. 2003. Growth of knowledge on the reptiles of India, with an introduction to systematics, taxonomy and nomenclature. Journal of the Bombay Natural History Society 100(2-3): 446-501.

Das, I. and S.K. Dutta. 1998. Checklist of the amphibians of India, with English common names. Hamadryad 23: 63-68.

Desai, A. 2017. Sarp Sandarbh. Gujarat na saap vishay ni Mahiti [= Regarding Snakes. Information about Snakes of Gujarat]. 6th ed. Prakruti Mitra Mandal, Dahod, Gujarat (in Gujarati).

Dowling, H.G. 1951. A proposed standard system of counting ventrals in snakes. British Journal of Herpetology 1(5): 97-99.

Dutta, S.K. 1997. Amphibians of India and Sri Lanka (Checklist and Bibliography). Odyssey Publication House, Bhubaneswar, Orissa, India.

Dutta, S. and K. Manamendra-Arachchi. 2004. Duttaphrynus scaber. The IUCN Red List of Threatened Species 2004: e.T54753A11199889.

Frost, D.R. 2019. Duttaphrynus scaber (Schneider, 1799). Amphibian Species of the World: An Online Reference. Version 6.0. American Museum of Natural History, New York. (http://research.amnh.org/vz/herpetology/amphibia/ Amphibia/Anura/Bufonidae/Duttaphrynus/Duttaphrynus-scaber).

Habib, B. and B. Cheda. 2010. Ninety-six young ones born to Russell's Viper, Daboia russelii. Reptile Rap 10: 20-21.

Khan, M.S. 2002. Riparian tadpoles of Punjab, Pakistan: Bufo stomaticus Lütkin, 1862. Bulletin of the Chicago Herpetological Society 37: 216-219.

Laxmi Narayana, B., G. Baburao, and V. Vasudeva Rao. 2016. Distribution of Treutler's Gecko (Hemidactylus treutleri Mahony, 2009) in Telangana and Andhra Pradesh, southern India - a general information. Reptile Rap 18: 25-28.

Manhas, A., R. Raina, and A. Wanganeo. 2018. Reptilian diversity and distributions in the Doda District of Jammu and Kashmir, India. Reptiles \& Amphibians 25: 164-169.

Parmar, D.S. 2017. Notizen zu Inkubation und Schlupf bei Coelognathus helena helena (Daudin, 1803) aus Gujarat, Indien. Sauria 39(3): 31-36.

Parmar, D.S. 2018a. Notes on the Checkered Keelback, Xenochrophis piscator (Schneider 1799), in Gujarat, India. Reptiles e Amphibians 25: 115-119.

Parmar, D.S. 2018b. Captive husbandry of Green Keelbacks, Macropisthodon plumbicolor (Cantor 1839). Reptiles \& Amphibians 25: 223-231.

Smith, M.A. 1935. The Fauna of British India, Including Ceylon and Burma. Reptilia and Amphibia. Vol. II.-Sauria. Taylor and Francis, London.

Smith, M.A. 1943. The Fauna of British India, Ceylon and Burma, including the whole of the Indo-Chinese Sub-region. Reptilia and Amphibia. Vol. III.Serpentes. Taylor and Francis, London.

Uetz, P., P. Freed, and J. Hošek (eds.). 2018. The Reptile Database (http://www. reptile-database.org).

Van Dijk, P.P., D. Iskandar, M.W.N. Lau, G. Huiqing, G. Baorong, L. Kuangyang, C. Wenhao, Y. Zhigang, B. Chan, S. Dutta, R.F. Inger, K. ManamendraArachchi, and M.S. Khan. 2004. Duttaphrynus melanostictus. The IUCN Red List of Threatened Species 2004: e.T54707A86445591 (errata version published in 2016).

Vyas, R.V. 1993. Studies of some snakes (Ophidia: Reptilia) of Gujarat State. Unpublished Ph.D. Thesis, Bhavnagar University, Bhavnagar, India.

Vyas, R. 2007. Herpetofauna of Purna Wildlife Sanctuary, Gujarat, India. Reptile Rap 8: 10-15.

Vyas, R. 2008. Review of the current diversity and richness of amphibians of Gujarat, India. The Indian Forester 134: 1381-1392.

Vyas, R. 2014. Notes and comments on the distribution of two endemic Lygosoma skinks (Squamata: Scincidae: Lygosominae) from India. Journal of Threatened Taxa 6: 6726-6732.

Whitaker, R. and A. Captain. 2004. Snakes of India: The Field Guide. Draco Books, Chennai, India.

Whitaker, R. and A. Captain. 2008. Snakes of India: The Field Guide. First reprint edition. Draco Books, Chennai, India. 